\title{
Abnormal skeletal and cardiac development, cardiomyopathy, muscle atrophy and cataracts in mice with a targeted disruption of the Nov (Ccn3) gene
}

\author{
Emma Heath ${ }^{1}$, Dalal Tahri ${ }^{1}$, Elisabetta Andermarcher ${ }^{1}$, Paul Schofield ${ }^{2}$, \\ Stewart Fleming ${ }^{3}$ and Catherine A Boulter*1
}

Address: ${ }^{1}$ Department of Genetics, University of Cambridge, Cambridge CB2 3EH, UK, ${ }^{2}$ Department of Physiology, Development and Neuroscience, University of Cambridge CB2 3EG, UK and ${ }^{3}$ Department of Pathology and Neuroscience, University of Dundee, Ninewells Hospital, Dundee DD1 9SY, UK

Email: Emma Heath - e.heath@gen.cam.ac.uk; Dalal Tahri - dalal.tahri@cliffordchance.com;

Elisabetta Andermarcher - eandermarcher@yahoo.fr; Paul Schofield - ps@mole.bio.cam.ac.uk; Stewart Fleming - s.fleming@dundee.ac.uk;

Catherine A Boulter* - cb@mole.bio.cam.ac.uk

* Corresponding author

Published: 20 February 2008

BMC Developmental Biology 2008, 8:18 doi:10.1186/147|-2/3X-8-18

This article is available from: http://www.biomedcentral.com/l47I-2I3X/8//8

(c) 2008 Heath et al; licensee BioMed Central Ltd.

This is an Open Access article distributed under the terms of the Creative Commons Attribution License (http://creativecommons.org/licenses/by/2.0), which permits unrestricted use, distribution, and reproduction in any medium, provided the original work is properly cited.
Received: 28 July 2007

Accepted: 20 February 2008

\begin{abstract}
Background: Signals from the extracellular environment control many aspects of cell behaviour including proliferation, survival, differentiation, adhesion and migration. It is increasingly evident that these signals can be modulated by a group of matricellular proteins called the $\mathrm{CCN}$ family. $\mathrm{CCN}$ proteins have multiple domains through which they regulate the activities of a variety of signalling molecules including TGF $\beta$, BMPs and integrins, thereby influencing a wide range of processes in development and disease. Whilst the developmental roles of CCNI and CCN2 have been elucidated, very little is known about the function of CCN3 (NOV). To investigate this, we have generated mice carrying a targeted mutation in the Nov gene (Novdel3) which reveal for the first time its diverse functions in embryos and adults.
\end{abstract}

Results: By replacing Nov exon 3 with a TKneomycin cassette, we have generated Novdel3-/- mice which produce no full length NOV protein and express at a barely detectable level a mutant NOV protein that lacks the VWC domain. In Novdel3_/- embryos, and to a lesser extent in Novdel3+/- embryos, development of the appendicular and axial skeleton was affected with enlarged vertebrae, elongated long bones and digits, delayed ossification, increased bone mineralization and severe joint malformations. Primary embryo fibroblasts from Novdel3_/- mutant embryos showed enhanced chondrogenesis and osteogenesis. Cardiac development was also influenced leading to enlargement and abnormal modelling of the endocardial cushions, associated with septal defects and delayed fusion. In adults, cardiomyopathy was apparent, with hypertrophy and calcification of the septum and left ventricle dilation. Muscle atrophy was seen by 5 months of age, associated with transdifferentiation to fat. Premature tissue degeneration was also seen in the lens, with cataracts present from 6 months.

Conclusion: We have generated the first mice with a mutation in the Nov gene (Novde/3). Our data demonstrate that NOV is a regulator of skeletal and cardiac development, and implicates NOV in various disease processes including cardiomyopathy, muscle atrophy and cataract formation. Novdel3 mutants represent a valuable resource for studying NOV's role in the modulation and co-ordination of multiple signalling pathways that underpin organogenesis and tissue homeostasis. 


\section{Background}

The behaviour of cells in development, tissue regeneration and disease is dependent upon multiple signals from the extracellular environment. These signals are mediated through a variety of signalling proteins that regulate cell proliferation, survival, differentiation, adhesion and migration. There is increasing evidence that a family of matricellular proteins, the CCN family, is a central player in regulating several of these signalling molecules (reviewed in [1]). By modulating their activities, CCN family members profoundly influence the behaviour of cells in development, wound healing, tissue homeostasis and in a range of diseases, including fibrosis and cancer.

There are six members of the CCN family: CCN1 (Cyr61), CCN2 (connective tissue growth factor, CTGF), CCN3 (Nov), CCN4 (WISP1), CCN5 (WISP2/rCOP-1) and CCN6 (WISP3) [2,3]. Their diverse effects are mediated by four cysteine-rich conserved domains which are shared by all members of the family, with the exception of WISP2 which lacks the C-terminal domain [2]. Through these domains, CCN proteins interact with a variety of extra-cellular signalling molecules, thereby regulating and potentially co-ordinating their activities. The first domain shares homology with insulin-like growth factor binding proteins (IGFBPs) and with Twisted gastrulation (Tsg) which modulates BMP signalling [4-6]. The second domain contains a Von Willebrand's factor type $\mathrm{C}$ repeat (VWC) and shares similarities with Short gastrulation (Sog)/Chordin; this domain in CTGF has been shown to enhance TGF $\beta$ binding to its receptor and inhibit BMP4 signalling [7]. The third domain contains a thrombospondin type 1 (TSP-1) repeat and in CTGF binds to the lowdensity lipoprotein (LDL) receptor-related protein 1 (LRP1) in a heparin-dependent manner [8,9]. The fourth carboxy- terminal (CT) domain is similar to the $\mathrm{C}$ terminus of Slit, which is involved in axon guidance and cell migration [10]. The CT domain mediates interactions with heparan sulphate proteoglycans $[11,12]$ and contains a cysteine knot, a structure found in several growth factors, including TGF $\beta$, platelet derived growth factor (PDGF) and nerve growth factors (NGFs) $[2,13]$. The CT domain of CTGF has been shown to interact with the Wnt co-receptor LDL receptor-related protein 6 (LRP6), thereby inhibiting Wnt signalling [14]; a similar domain is also present in another novel modulator of Wnt signalling, WISE [15] and modulation of Wnt signalling through this domain has also been demonstrated for Cyr61 [16]. Finally, many of the effects of different CCN family members involve signalling through a variety of integrins which interact specifically with different domains in the CCN proteins [17].

$\mathrm{CCN}$ proteins have a diverse range of activities in development and disease, and different family members mediate cell adhesion and migration, affect cell proliferation and survival, and influence angiogenesis, chondrogenesis and wound healing [18-23]. The involvement of two CCN proteins in regulating different aspects of development has been revealed by generating mutant knockout mice. Targeted disruption of CTGF identified a role in coordinating chondrogenesis and angiogenesis [24], while knock out mice lacking CYR61 show that it is required for placental development and vascular integrity [25]. Mutations in a third CCN gene, WISP3, cause progressive pseudorheumatoid dysplasia in man [26].

Nov was originally isolated from a chick nephroblastoma induced by infection of new born chicks with the MAV-1 avian retrovirus [27]. Nephroblastomas (Wilms' Tumours in humans) arise from the blastemal cells of the kidney and are characterised by abnormal proliferation and aberrant differentiation of this stem cell population. Whilst Nov is over-expressed in all nephroblastomas and Wilms' tumours studied $[28,29]$ a direct causative link with Nov and tumour formation has only recently been demonstrated, with the isolation of a second independent proviral insertion in another virally-induced chick nephroblastoma [30]. The observation that Nov expression is deregulated in a variety of other tumour types, including musculoskeletal tumours [31] suggests that NOV may have a more general involvement in tumourigenesis.

The expression pattern of Nov during mammalian embryogenesis is consistent with a developmental role in a variety of tissues, including the cardiovascular system, skeleton, muscle and structures of the nervous system derived from the neural crest and placodes [32,33]. To investigate the function of NOV, we have generated mice carrying a targeted mutation in the Nov gene. Here we show that mutation of Nov leads to abnormal skeletal and cardiac development, to joint abnormalities, cardiomyopathy, and premature tissue degeneration causing muscle atrophy and cataracts in adult mice.

\section{Results}

Generation of mice carrying a targeted mutation in Nov

Novdels mutant mice were generated by replacement of exon 3 with a Tkneomycin selection cassette (Figure $1 \mathrm{~A}, \mathrm{~B})$, resulting in the targeted allele encoding a protein that lacks the VWC domain. Both the wild type and targeted Nov alleles were expressed in primary embryonic fibroblasts (PEFs) derived respectively from wild type and Novdel3_/- E13.5 embryos (see Additional file 1). However, Western blotting showed that NOV protein was undetectable in whole cell lysates of Novdel3_/- PEFs, whereas it was expressed highly in PEFs from wild type littermates (Figure $1 \mathrm{C}$ ). We were also unable to detect any full length NOV protein in conditioned medium from Novdels_/-cells, 


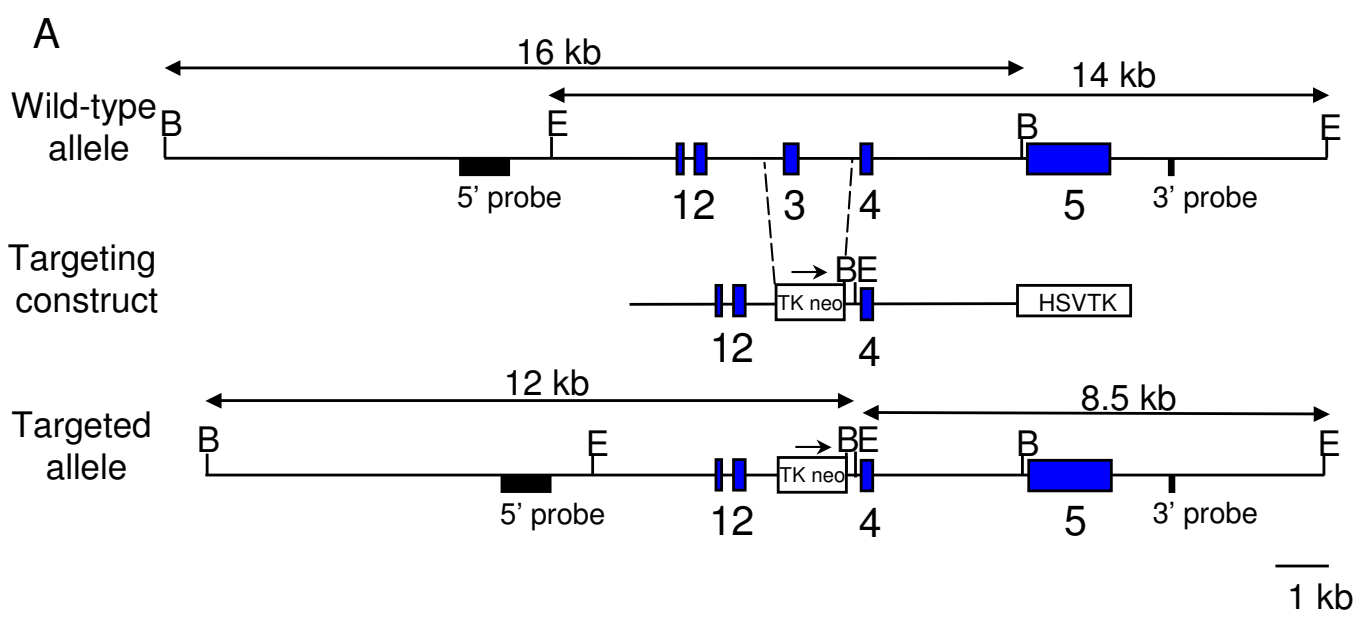

B

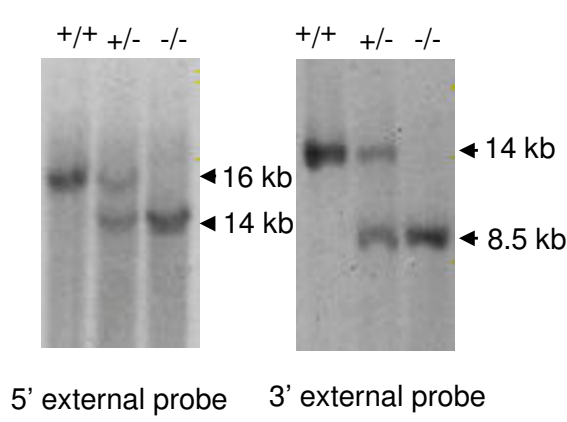

C

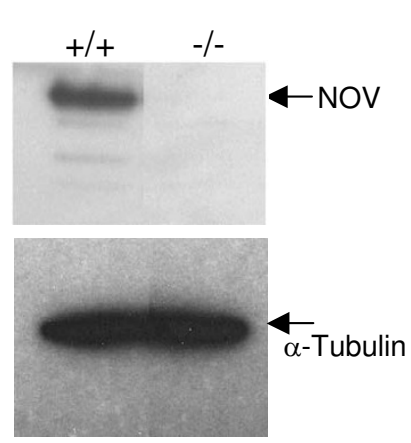

Whole cell lysate

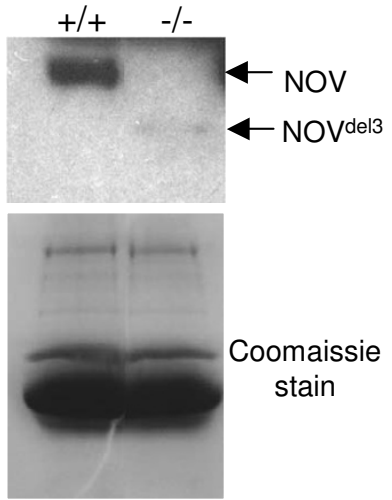

Conditioned media

\section{Figure I}

Gene targeting at the Nov locus. A. Schematic diagram showing wild type and targeted Nov alleles, the targeting construct, and the positions of the $5^{\prime}$ and 3 ' external probes used to confirm targeting by Southern blotting. The TkneopolyA cassette replaces exon 3 in the targeted allele while the HSV TK cassette allows negative selection with Gancyclovir. B. Southern analysis of DNA from wild type, heterozygous and homozygous embryos using 5' and 3' external probes to confirm targeting. Digestion with BamHI gave a $16 \mathrm{~kb}$ wild type band with the 5 'external probe and $14 \mathrm{~kb}$ targeted allele with the 5 ' probe, while digestion with EcoRI gave a I4 kb wild type band and $8.5 \mathrm{~kb}$ targeted band with the 3 ' probe. C. Western blotting of whole cell lysates and conditioned media from Novdel3 homozygous and wild type EI3.5 PEFs, using an anti-NOV antibody (59.3). Although NOV protein is readily detectable in wild type PEF whole cell lysates, no NOV protein can be detected in Novdel3 homozygous PEFs. Conditioned medium from wild type PEFs contains high levels of secreted NOV, whereas that from Novdel3_/- PEFs contains trace amounts of mutant NOV protein lacking the VWD domain.

but we could detect trace amounts of the mutant protein lacking the VWC domain. This was present at an extremely low level compared to that of the full length NOV protein in conditioned medium from wild-type PEFs, suggesting that deletion of the VWC domain might lead to reduced protein stability (Figure 1C).

Analysis of genotype ratios of offspring of F1 and F2 heterozygous matings indicated that there was loss of $35 \%$ of heterozygotes and $55 \%$ of homozygotes prior to post natal day10, with loss of $10 \%$ heterozygous and $20 \%$ homozygous embryos isolated at E13.5-E19.5 (Table 1).
Table I: Genotypes of Offspring from Matings of FI and F2 Novdel3 heterozygotes

\begin{tabular}{lrrrr}
\hline & $\begin{array}{c}\text { Number } \\
\text { of litters }\end{array}$ & Novdel3 -/- & Wild type & Nordel3+/- \\
\hline Embryos EI2.5-EI9.5 & 15 & 22 & 28 & 50 \\
Ratio: wild type & & 0.8 & 1.0 & 1.8 \\
\% Loss & & 20 & 0 & 10 \\
Live born >PI0 & 7 & 5 & 11 & 14 \\
Ratio: wild type & & 0.45 & 1.0 & 1.3 \\
\% Loss & & 55 & 0 & 35 \\
\hline
\end{tabular}


Surviving Novdel3+/- and Novdel3_/- littermates were in apparent good health, and as adults were both viable and fertile. Successive generations showed reduced levels of neonatal loss, possibly reflecting selection for a less severe phenotype.

\section{Skeletal development is affected in Novdel3 homozygotes and heterozygotes}

Analysis of skeletons isolated from embryos at late gestation (E18.5 and E19.5) indicated abnormalities in Novdel3_ /- embryos ( $\mathrm{n}=6 / 6)$ and, with lesser severity, in $\mathrm{Nov}^{d e l}+$ / - embryos $(n=8 / 8)$, compared to wild type embryos $(n=$ $0 / 3$ ). Mutant skeletons were larger than those of wild type littermates and showed evidence of overgrowth of skeletal elements with enlarged vertebrae, elongated long bones and digits (Figure 2). Heterozygous and homozygous mutants had barrel-chested rib cages which might have contributed to the neonatal deaths observed (Figure 2A). Joint defects were also apparent, including fusion of the tarsal bones in the foot (Figure 2B), flattening of the patella (Figure 2C), malformation of the wrist (Figure 2D), dislocation of the hip (Figure 2E) and abnormal articulation of the joints resulting in laxity of the limbs. Abnormalities in segmentation of the caudal vertebrae were also observed in some animals, causing kinking of the tail (Figure 2F).

These skeletal abnormalities were also manifest in adult homozygotes, and to a lesser extent in adult heterozygotes, on staining skeletal preparations with Alcian blue and Alazarin red. In the mutants, but not in wild types, we observed overgrowth of the appendicular and axial skeleton, with increased length of the long bones (Figure 2G) and enlarged vertebrae (Figure $2 \mathrm{H})\left(\mathrm{Nov}^{\text {del }} 3 /-\mathrm{n}=6 / 6\right.$; $\mathrm{Nov}^{\text {del } 3}+/-\mathrm{n}=4 / 6$; wild type $\mathrm{n}=0 / 5$ ). Joint abnormalities were also seen with knee deformities being particularly prominent, characterised by expansion of the meniscus (Figure 2I) and abnormalities of the articular surfaces (Figure 2I,J) (Novdel3-/- $\mathrm{n}=6 / 6$; Nov ${ }^{\text {del3 }}+/-\mathrm{n}=4 / 6$; wild type $n=0 / 5$ ). Compared to wild type littermates, the skulls of heterozygotes and homozygotes were slightly larger and flatter (data not shown).

\section{Abnormal chondrocyte differentiation}

The expression pattern of Nov is consistent with a role in skeletal development. We have shown that it is expressed in the mesenchyme surrounding cartilage condensations, and in the tendons and myotendenous junctions at E16.5 in the mouse (Figure $3 \mathrm{~A}, \mathrm{~B}$; [32]), while others have reported expression in pre-hypertrophic and hypertrophic cartilage [34]. To investigate the origin of the skeletal abnormalities, skeletal preparations were made from embryos at E16.5. Alcian blue staining indicated that the cartilage elements were already enlarged in the Novdel3-/$(\mathrm{n}=2 / 2)$ and Novdel3 $+/$ - embryos $(\mathrm{n}=4 / 4)$, while Alizarin red staining of bone indicated a delay in ossification of the digits and vertebrae in the mutants $(n=5 / 6)$ compared to their wild type littermates $(n=0 / 3)$ (Figure $3 \mathrm{C}-\mathrm{G})$. The tightly ordered sequential ossification of the vertebrae seen in wild type embryos was disrupted in the mutants, indicating a defect in the normal differentiation of cartilage to bone (Figure 3E-G). However, once ossification did occur the intensity of Alizarin red staining was greater in the homozygotes $(\mathrm{n}=2 / 2)$ and heterozygotes ( $\mathrm{n}$ $=4 / 4)$ than in wild type embryos $(n=0 / 3)$, suggesting increased bone mineralization (Figure 3C,D). This was also observed in mutant embryos at E18.5 (data not shown) and E19.5 (Figure 2A-F).

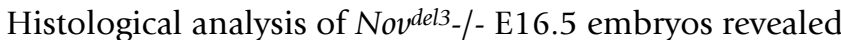
abnormalities in chondrogenesis $(n=4 / 4)$ which were not apparent in wild type littermates $(n=0 / 4)$. Haematoxylin and Eosin stained sections from Novdel3_/- embryos showed morphological differences in the pre-hypertrophic and hypertrophic cartilage and their surrounding matrix (Figure $3 \mathrm{~J}, \mathrm{~K}, \mathrm{~L}, \mathrm{M}$ ). The chondrocytes adjacent to the perichondrium near the junction with the periosteum were enlarged compared with chondrocytes from wild type embryos (Figure 3J,K), with increased thickness of the perichondrium and periosteum compared to wild type littermates (Figure $3 \mathrm{H}-\mathrm{M}$ ). Alcian blue staining confirmed increased size of the cartilage elements in the $N o v^{d e l 3}$-/- embryos and indicated blurring of their boundaries, showing that the demarcation between mesenchyme and chondrocytes seen in the wild type embryos was absent in the mutants, and suggesting an expansion of the chondrocyte domain (Figure $3 \mathrm{~L}, \mathrm{M}$ ). On staining with an antibody against the proliferation marker PCNA the sharp junction of proliferating columnar chondrocytes with non proliferating pre-hypertrophic chondrocytes seen in wild type sections was absent in the homozygous mutants, suggesting that the ordered transition from the columnar to pre-hypertrophic state was disrupted (Figure $3 \mathrm{~N}, \mathrm{O}$ ). Von Kossa staining for mineralized bone also confirmed a shortening of the bone collar in the pre-hypertrophic/hypertrophic region $(n=4 / 4)$ compared with the wild type control $(n=0 / 4)$, consistent with a reduction in the size of this zone, while the bone collar itself was thicker and stained more intensely, indicating a greater quantity of mineralized bone matrix (Figure 3P,Q).

\section{Enhanced chondrogenesis and osteogenesis of $\mathrm{Nov}^{\mathrm{del}}$ _/- fibroblasts}

We hypothesised that the enlarged cartilage elements and increased bone mineralization seen in Novdel3-/- embryos might reflect increased chondrogenesis and osteogenesis. We therefore determined whether primary embryo fibroblasts (PEFs) from Novel3-/- embryos showed enhanced participation in chondrogenesis and/or osteogenesis. 

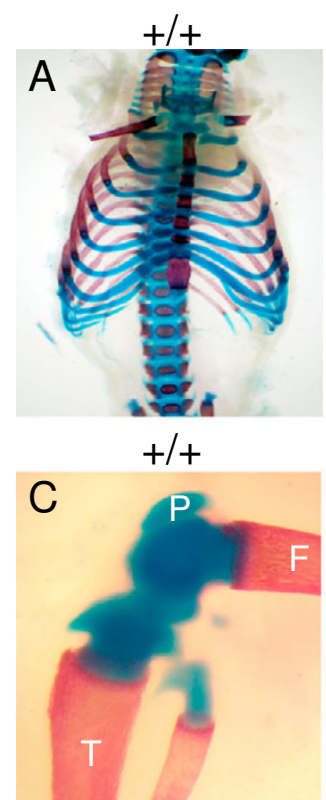

$+/+$

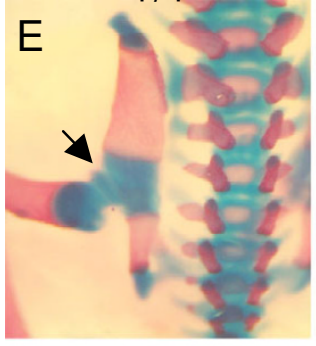

$-1-$

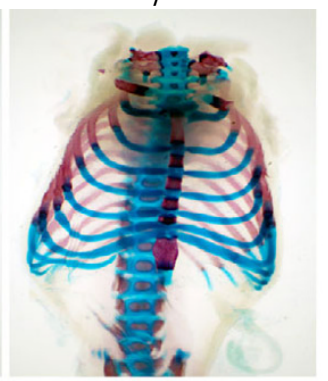

$-1-$

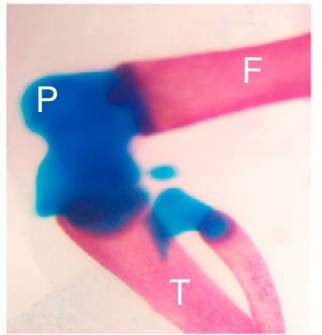

$-1-$

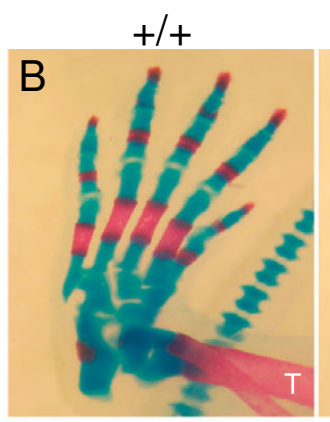

$+/+$
$-1-$

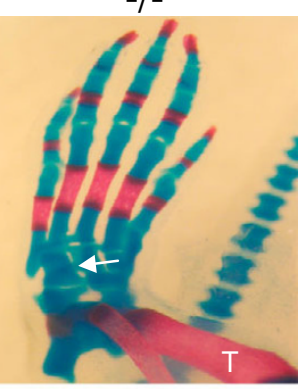

$-1-$
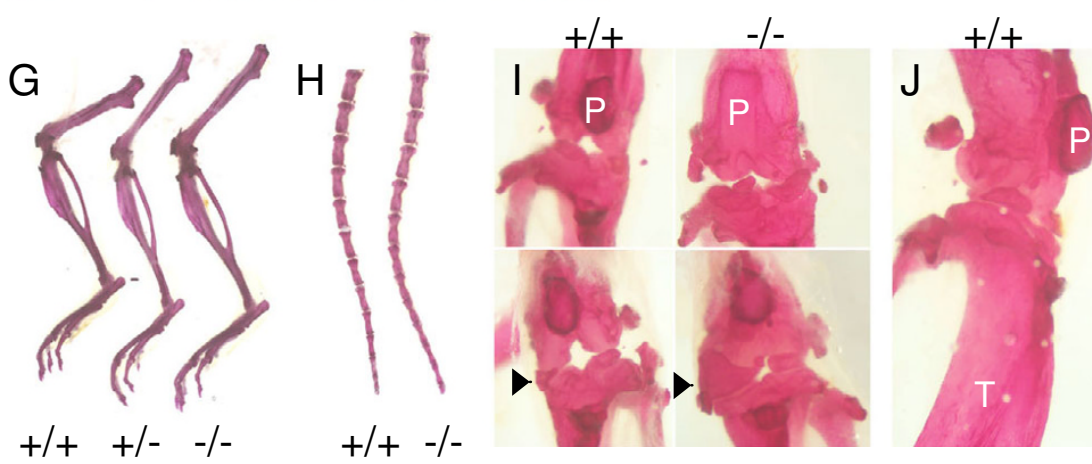

$-1-$
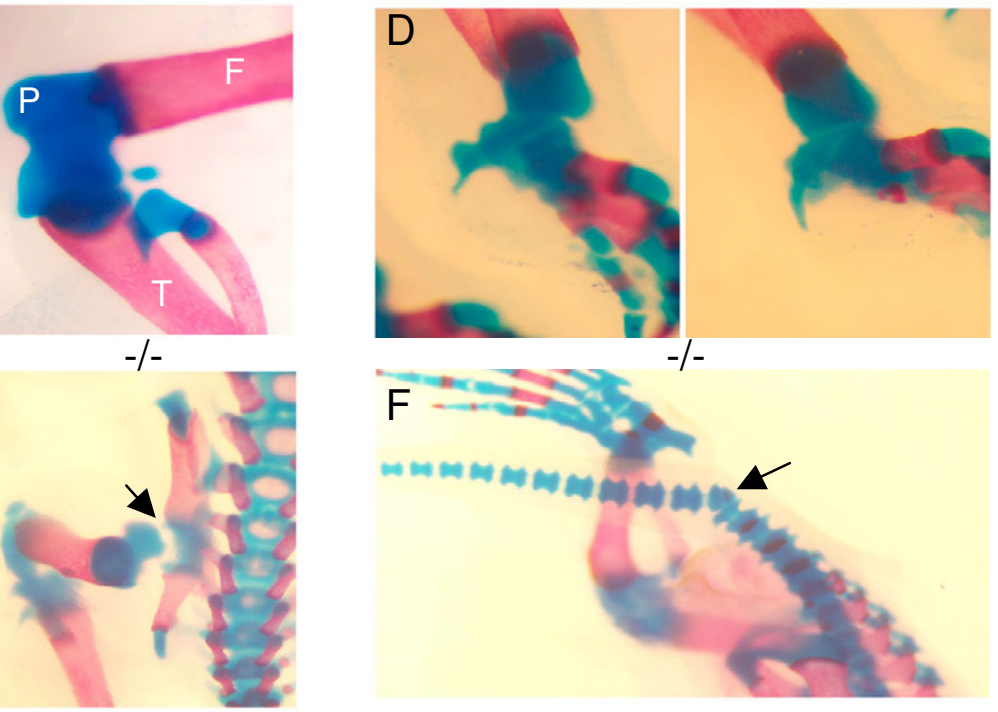

$+/-1-$

$+/+-/-$

\section{Figure 2}

Skeletal staining of wild type and Novdel3_/- El9.5 embryos and adults with Alcian blue (cartilage) and Alizarin red (bone). A-F: Novdel3_/- El9.5 embryos. A. Staining of rib cages showing barrel chest in Novdel3 _/- with overgrowth of ribs. B. Hind foot showing fusion of the tarsal cartilage elements (white arrow) and elongation of the digits in Novdel3 -/-. Note increased intensity of Alizarin red staining and thickening of the tibia in Novdel3_/- compared to wild type. C. Knee abnormalities in Novdel3-/- compared with wild type, including flattening of the patella. D. Malformation of the wrist elements in Novdel3 -/compared to wild type. E. Dislocation of hip (arrow) in Novdel3-/- compared to wild type. F. Kinking of tail with compression of the vertebral body (arrow) in Novdel3 -/- embryo. G-J: Adult skeletons. Overgrowth of the appendicular skeleton in Novdel3 -/-, and to a lesser extent in Novdel3 +/-, compared to wild type $(+/+)$ littermate. H. Overgrowth of the axial skeleton in Novdel3-/compared to wild type, with increased length of individual vertebral bodies. I. Frontal view of right (upper panel) and left (lower panel) knee joints from Novdel3-/- and wild type (+/+) littermates showing abnormal patella (P) and grossly enlarged medial meniscus (arrow head) in mutant compared with wild type. J. Lateral view of knee showing flattening of patella in Novdel3-/-. F: femur; T: tibia and P: patella. 

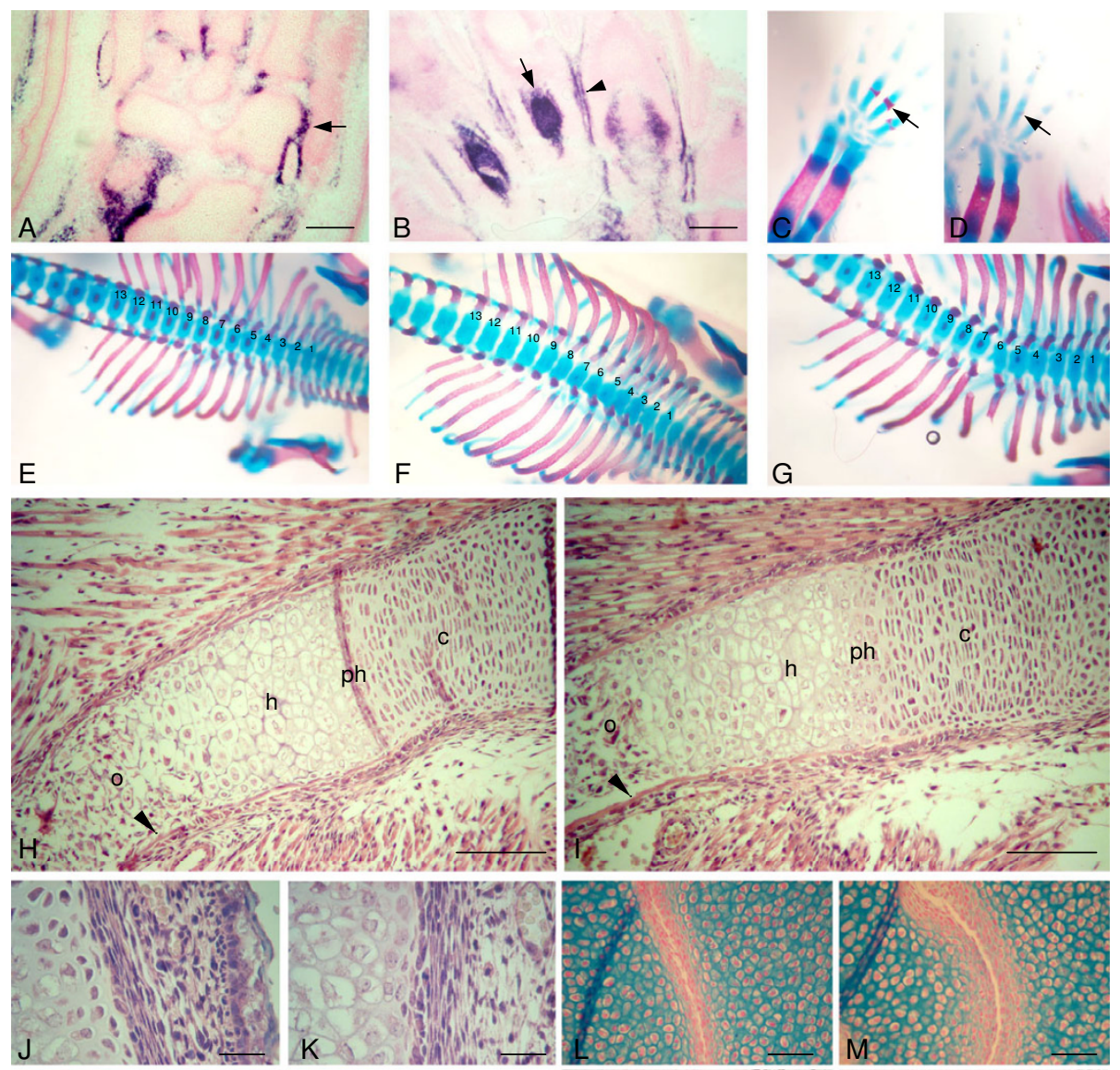

$\mathrm{F}$

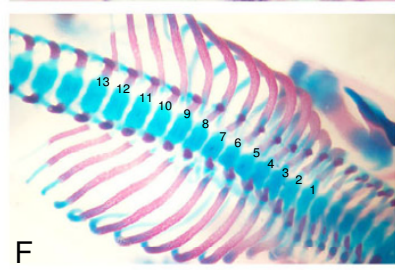

G

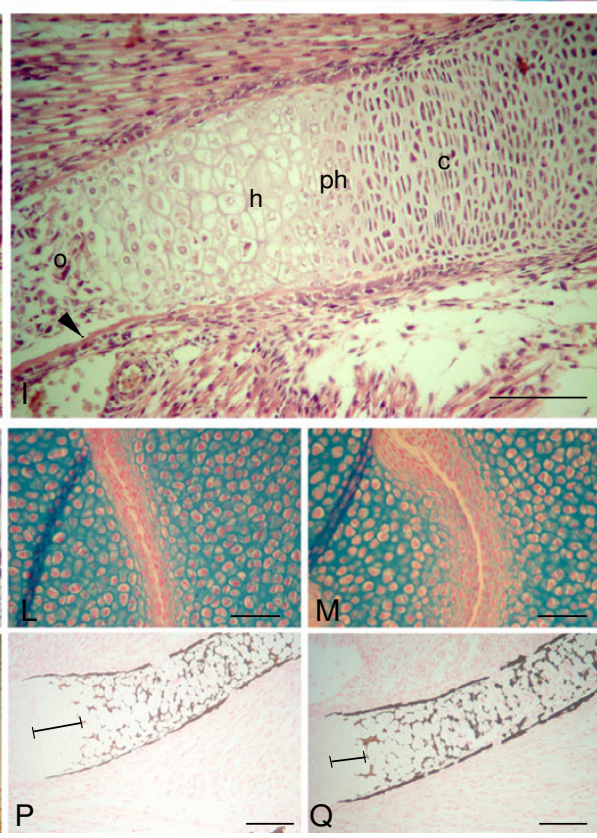

Figure 3

Nov expression and phenotypes of E I6.5 skeletons. A and B. RNA in situ hybridization showing Nov expression in the hind foot at El6.5. A. Strong expression in the myotendenous junctions (arrow) and in the mesenchyme of the joints adjacent to the cartilage elements, but no expression in condensing cartilage. B. High expression in the mesenchyme overlying the cartilage elements (arrow) and in the digital tendons (arrow head). C-G. Skeletal staining with Alizarin red and Alcian blue of El6.5 Novdel3+/-, Novdel3 $/-$ and wild type (+/+) embryos. C. Wild type forefoot showing ossification of digits (arrow). D. No ossification in Novdel3-/- digits (arrow), but intense staining with Alizarin red of the radius and ulna indicating increased bone mineralization. E-G Vertebrae and rib cages of wild type (E), Novdel3-/- (F) and Novdel3 $+/-(\mathrm{G})$ showing delay in ossification of the vertebrae in the mutant embryos. No ossification is present in the Novdel3-/- embryo, and whilst ossification is taking place in the Novdel3+/- embryo (G), it is not occurring in the ordered, sequential manner observed in the wild type. Thoracic vertebrae numbered I-I3. H-Q. Histological sections of El6.5 wild type and Novdel3_/- embryos. H, J, L, N, P: wild type; I, K, M, O, Q: Novdel3_/- littermate. H, I: Haematoxylin and Eosin stained sections showing expanded perichondrium and periosteum in Novdel3. /- and a thicker bone collar (arrow head) compared to the wild type. o: ossified bone; h: hypertrophic cartilage; ph: pre-hypertrophic cartilage; c: columnar chondroctyes. J, K: Haematoxylin and Eosin stained sections at higher magnification at the junction of pre-hypertrophic/hypertrophic chondrocytes, adjacent to the border of the perichondrium/periosteum, showing abnormal morphology of chondrocytes and matrix in the mutant (K). L, M: Alcian blue staining of cartilage, showing expansion of the cartilage element and blurring of its borders in the Novdel3-/- embryo (M) compared to wild type (L). N, O: PCNA staining showing a sharp demarcation (black dashed line) between proliferating chondrocytes and pre-hypertrophic chondroctes in the wild type $(\mathrm{N})$, but not in the Novdel3-/- mutant (black dashed line) (O). P, Q: Von Kossa staining for mineralised bone showing a shorter and thicker bone collar (indicated by the black bar) in the pre-hypertrophic/hypertrophoic zone of the Novdel3-/mutant (Q) compared to wild type (P). Scale bars in A B = $20 \mu \mathrm{m} ; \mathrm{H}, \mathrm{I}, \mathrm{N}, \mathrm{O}, \mathrm{P}, \mathrm{Q}=10 \mu \mathrm{m} ; \mathrm{J}-\mathrm{M}=5 \mu \mathrm{m}$. 
Three independent wild type PEF cell lines and three $N o v^{d e l 3}$ homozygote cell lines were isolated from individual E13.5 embryos and explanted as micromasses. After culturing for 5 and 9 days, the micromasses were stained with Alcian blue as a marker of chondrogenesis and alkaline phosphatase for osteogenesis. After 5 days, the Novdel3_/- micromasses stained more intensely with Alcian blue than did the controls (Figure 4A,E) and by 9 days had increased significantly in diameter compared to wild type micromasses (Figure 4B,F). Osteogenic differentiation was also observed in the Novdel3_/- micromasses: weak alkaline phosphatase activity was detected in the Novdel3-/ - micromasses at day 5, with strong staining at day 9 , in contrast to control cultures which were negative at both time points. Hence, both chondrogenesis and osteogenesis were enhanced in the Novdel3-/- micromasses.

We next investigated whether the osteogenesis seen in the $\mathrm{Nov}^{\text {del3 }}$-/- micromass cultures was a result of an increased tendency of $\mathrm{Nov}^{\text {del3 }}$ /- mesenchymal cells to differentiate down this pathway. Three independent Novdel3 -/- cell lines and three control wild type cell lines were plated at passage 2 and cultured for 10 days in DMEM with 10\% FCS, after which they were stained for the osteoblast marker alkaline phosphatase. In contrast to the control cultures which retained a fibroblast phenotype and were negative for the osteoblast marker (Figure $4 \mathrm{I}, \mathrm{J}$ ), the Novdel3 -/- cultures showed extensive staining (Figure $4 \mathrm{~K}, \mathrm{~L}$ ). RTPCR performed on two independent wild type and homozygous cultures showed high expression of the osteoblast markers alkaline phosphatase and collagen I in the Novdel3_/- cultures, but not in the wild type cell lines, with one of the mutant cell lines exhibiting increased expression of the later osteogenic marker osteocalcin (Figure 4M).

\section{Abnormal development, cardiomyopathy and calcification of Novdel3 mutant hearts}

During mouse heart development, Nov is expressed highly in the endothelial and smooth muscle cells of the aortic outflow tract from E12.5 and in a subset of cells near the origins of the great vessels (Figure 5A,B; [32]). Defects in heart development were observed in E13.5 Novdel3_/embryos. Haematoxylin and eosin stained transverse serial sections showed abnormal growth and modelling of the endocardial cushions $(n=4 / 4)$; these were enlarged and exhibited a broader base extending laterally compared to wild type littermates $(n=0 / 3)$ (Figure 5C-F; Additional file 2). Abnormalities in development of the septum were also seen, namely thickening of the septum and a delay in fusion with the endocardial cushions (Figure $5 \mathrm{D}, \mathrm{F})$. No heart defects were observed in wild type littermates $(n=0 / 3)$. Serial transverse sectioning of adult hearts showed that Novdel3-/- mice $(\mathrm{n}=3 / 3)$, and to a lesser extent $\mathrm{Nov}^{d e l 3}+/$ - mice $(\mathrm{n}=3 / 3)$, exhibited defects at the caudal end of the septum near the origins of the great vessels, including hypertrophy of the septum towards the right ventricle and accumulation of blood in the subendothelial space between the right ventricle and septum; these defects were not observed in wild type littermates (n $=0 / 3$ ) (Figure 5G-K). Hypertrophic cardiomyopathy of the right and left ventricles and ventricular dilation suggestive of cardiac failure were noted in both homozygous and heterozygous Nov mutants, but not wild types (Figure $5 \mathrm{G}-\mathrm{K})$. Staining with Von Kossa indicated that areas of calcification were also present, most markedly on the septal wall of the right ventricle (Figure $5 \mathrm{~K}-\mathrm{M}$ ). Deposition of calcium was within morphologically normal myocardial tissue and there was no evidence of fibrous scarring, but occasionally a giant cell response to the calcium deposit was noticed. Venous dilation and congestion was observed in the kidney, liver and other organs, but the major arteries appeared normal.

\section{Tissue degeneration in adult Novdel3 homozygotes and heterozygotes}

The sites of Nov expression during mouse muscle development are in the lateral dermomyotome, in the subcutaneous muscle and in a subset of hypaxial muscles, notably the hip, shoulder, body wall, inter-costal and inter-vertebral muscles, but not muscles of the limb (Figure 6A; [32]). We noted that the body walls of Novdels homozygous adults $(n=11 / 11)$, and to a lesser extent heterozygotes $(n=19 / 20)$, were abnormally thin and more transparent than those from wild type littermates $(n=0 /$ 15) (Figure 6B,C). Other muscles that normally express Nov were severely affected in both adult homozygotes and to a lesser extent heterozygotes. From five months of age, these muscles exhibited areas of degeneration characterised by atrophy and trans-differentiation to immature adipose cells. In the subcutaneous muscles the extent of muscle atrophy could be clearly observed in the mutants, with a very thin line of residual muscle cells demarcating the normal junction of the subcutaneous fat and muscle layers; no atrophy was seen in their wild type littermates (Figure 6D-I). The cells in the immature adipose tissue had a characteristic bubbly cytoplasmic morphology and small size, in contrast to the large regular mature adipose cells present in the normal subcutaneous adipose tissue (Figure $6 \mathrm{~J}, \mathrm{~K}$ ). The process of muscle atrophy was clearly observed in the intercostal muscles with trans-differentiation to fat occurring within the muscle tissue (Figure 6L).

Early onset tissue degeneration was also seen in the lens with cataracts present in the eyes of both Novdel3-/- ( $\mathrm{n}=$ 10/23) and Novdel3 +/- $(\mathrm{n}=9 / 28)$ mice between six and thirteen months of age but not in wild type mice of similar age $(n=0 / 14)$ (Fig 7A,B). Haematoxylin and Eosin stained sections of wild type and homozygous adult eyes showed vacuolation of the degenerating lenses in the 


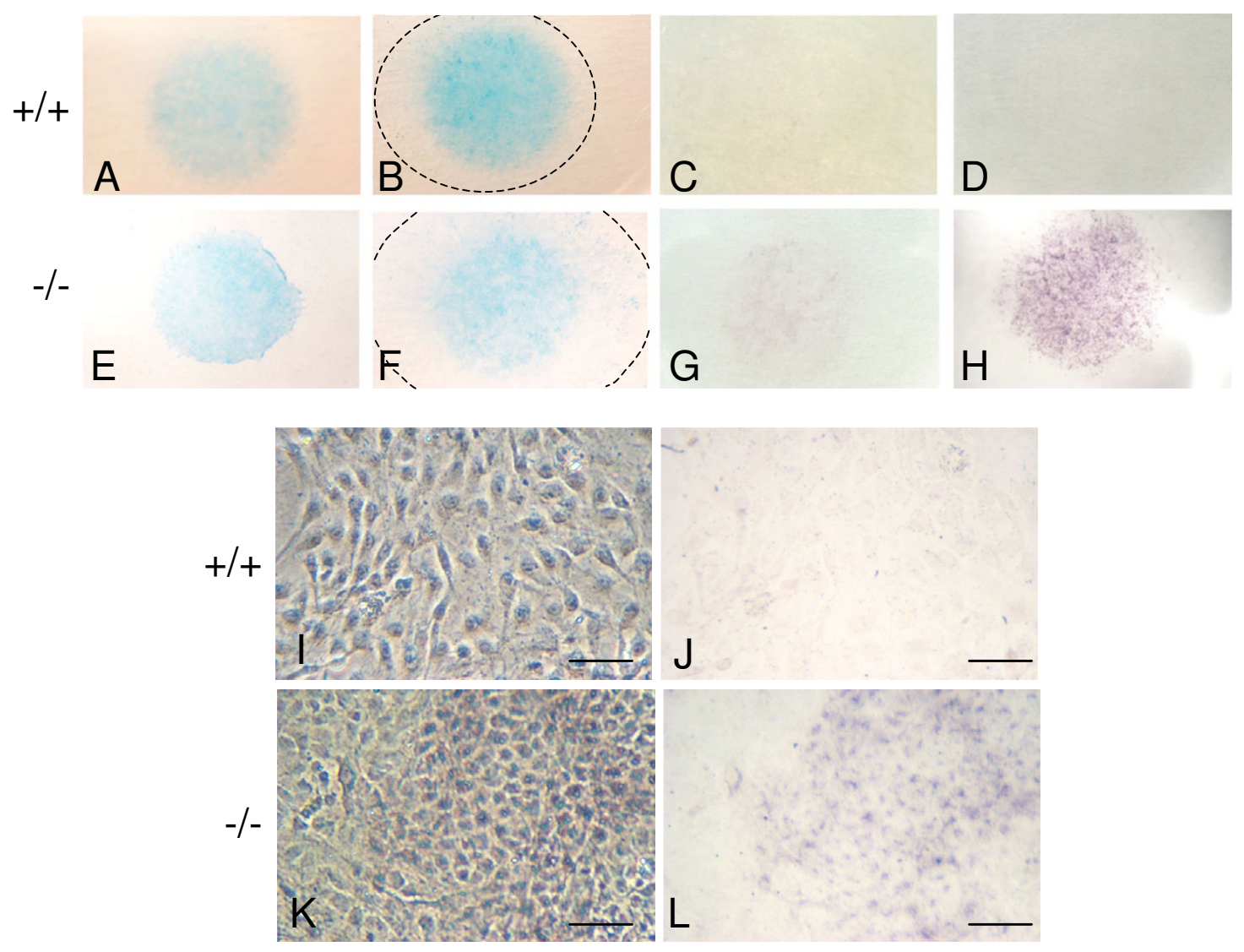

M
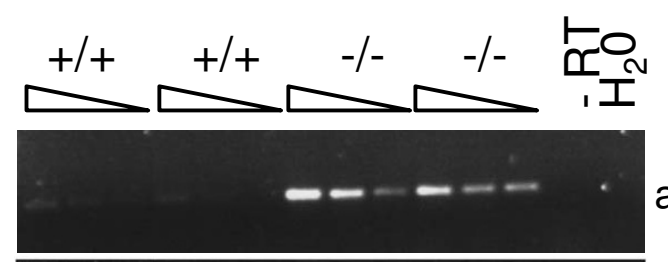

alkaline phosphatase

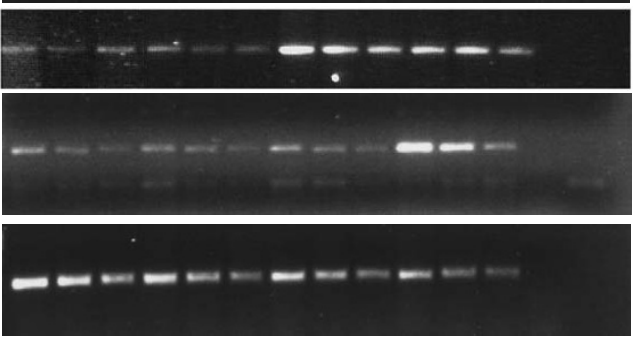

collagen I

osteocalcin

gapdh

\section{Figure 4}

Enhanced chondrogenesis and osteogenesis in Novdel3_/- PEFs. A-H: Staining of micromass cultures of PEFs derived from wild type (A-D) and Novdel3-/- (E-H) embryos. Alcian blue staining after 5 days $(A, E)$ and 9 days (B, F) in culture showing enhanced cartilage differentiation in Novdel3-/- cells, with the dashed line in B and F marking the extent of the micromass. Alkaline phosphatase staining after 5 days $(C, G)$ and 9 days $(D, H)$ in culture showing enhanced osteoblast differentiation in Novdel3. /- cells. I-L: Morphology of monolayer PEF cultures derived from wild type (I, J) and Novdel3-/- (K,L) embryos with (I, K) and without $(\mathrm{J}, \mathrm{L})$ phase contrast. Alkaline phosphatase staining after 10 days in culture $(\mathrm{I}, \mathrm{J}, \mathrm{K}, \mathrm{L})$ showing osteoblast differentiation in the Novdel3-/- PEFs but not in the wild type PEFs. Scale bar in I-N = $10 \mu \mathrm{m}$. M: Semi quantitative RT-PCR of mRNA from wild type $(+/+)$ and Novdel3-/- PEFs using primers for alkaline phosphatase, collagen I and osteocalcin. Two fold serial dilutions of cDNA were used and normalised to gapdh. 


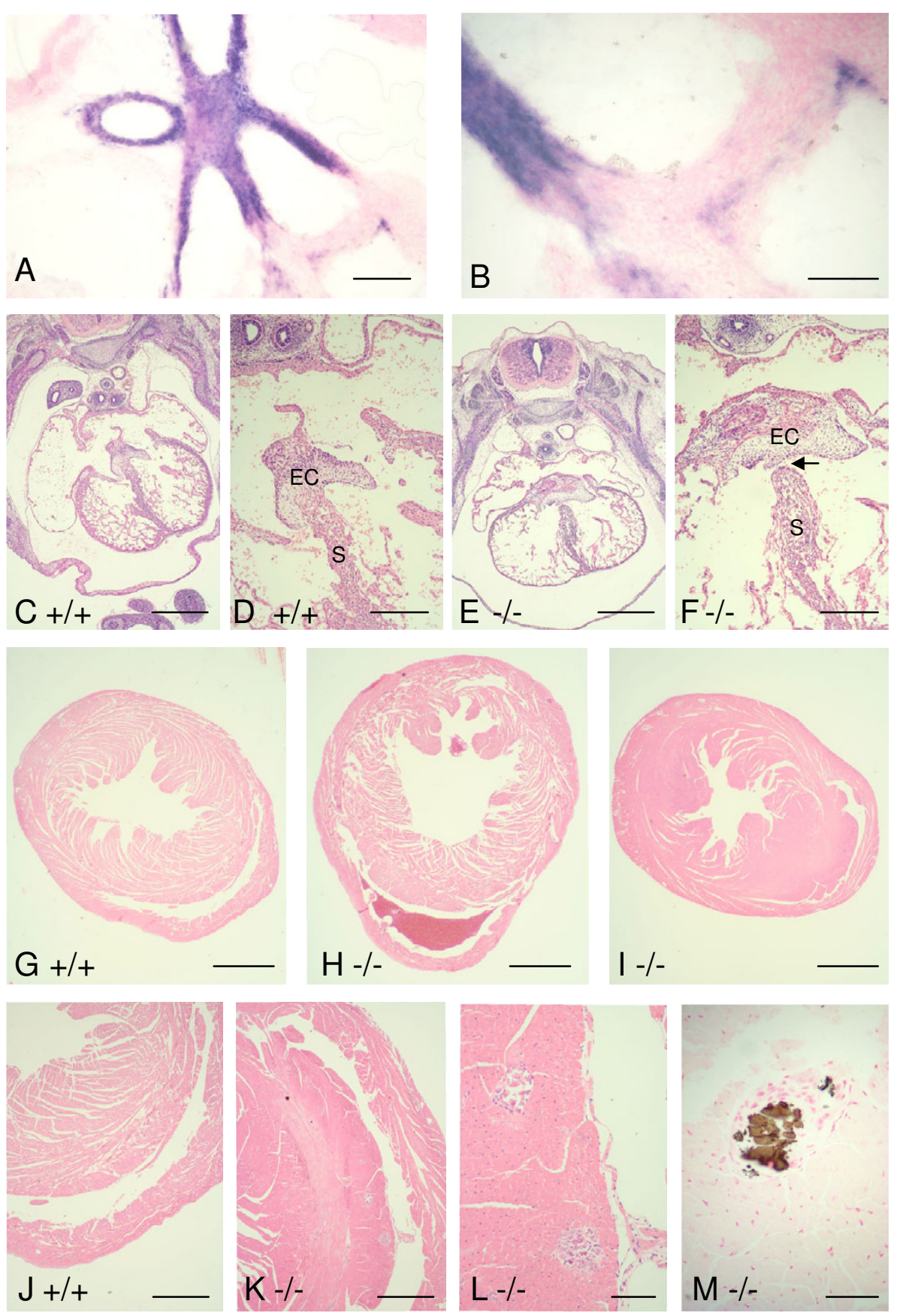

\section{Figure 5}

Nov expression and histology of embryonic and adult hearts. A, B: RNA in situ hybridization showing Nov expression in the endothelial and smooth muscle cells of the aortic outflow tract, pulmonary trunk and in a subset of cells near the origins of the great vessels at EI6.5. C-F: Haematoxylin and Eosin stained sections of wild type (C,D) and Novdel3-/- (E,F) EI3.5 embryonic hearts showing abnormal expansion of the endocardial cushions (EC) and delay in fusion of the septum (S) in the mutant mouse (arrow). G-M: Haematoxylin and Eosin stained sections of wild type (G, J) and Novdel3-/- (H, I, K) adult hearts, showing accumulation of blood in the sub-endothelial space between the right ventricle and septum $(H)$ and hypertrophy of the septum near the origins of the great vessels, $(\mathrm{H}, \mathrm{I}, \mathrm{K})$. Areas of calcification on the septal wall of the right ventricle $(\mathrm{K}, \mathrm{L})$, stain with $\mathrm{Von}$ Kossa (M). There is no associated fibrosis. Scale bars in A,D,F=20 $\mathrm{m} ; \mathrm{B}, \mathrm{L}=10 \mu \mathrm{m} ; \mathrm{C}, \mathrm{E}=50 \mu \mathrm{m} ; \mathrm{G}, \mathrm{H}, \mathrm{I}=\mathrm{I} \mathrm{mm} ; \mathrm{J}, \mathrm{K}=50 \mu \mathrm{m}$; $M=5 \mu \mathrm{m}$. 

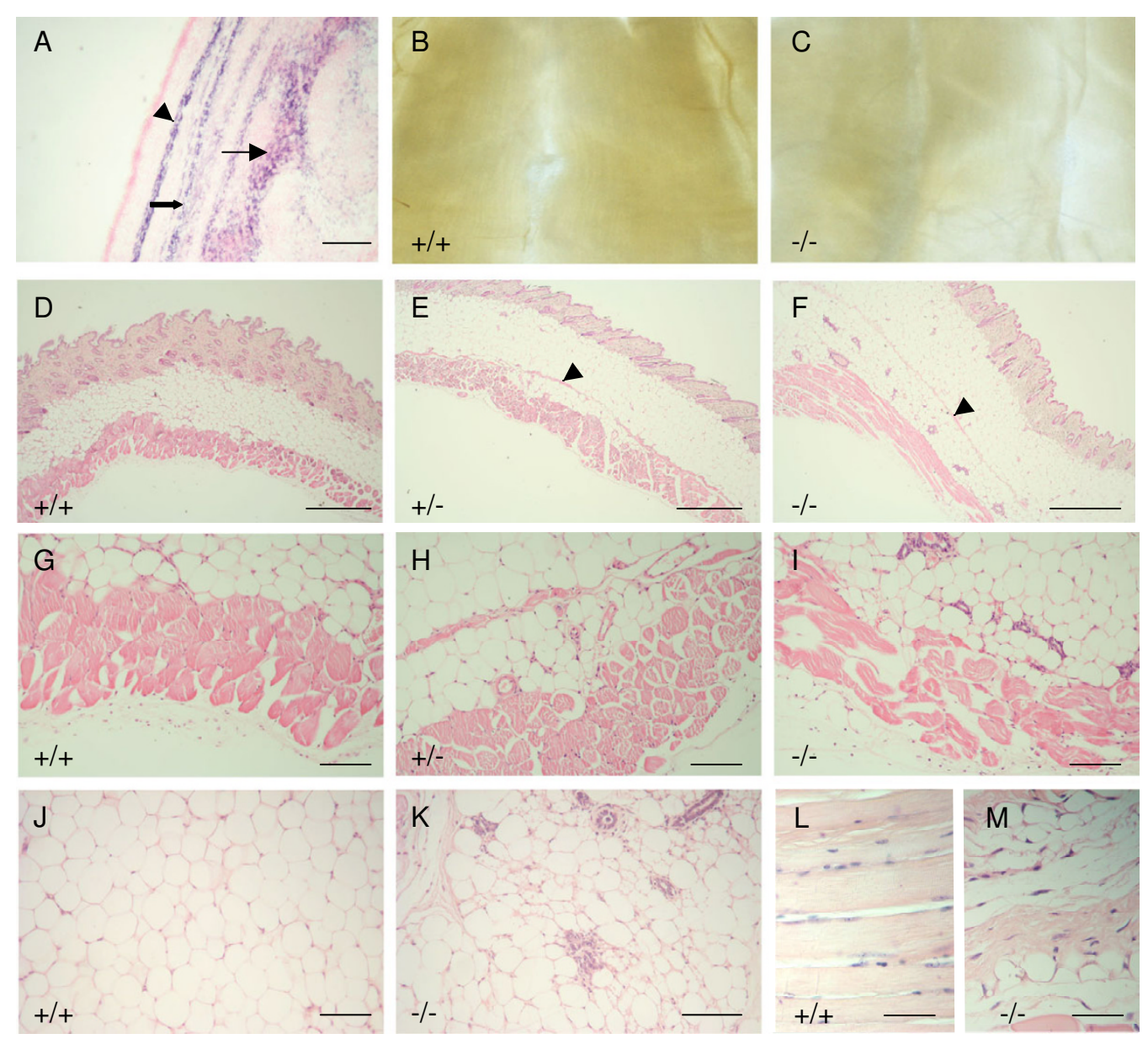

\section{Figure 6}

Nov expression and phenotype of subcutaneous and hypaxial muscles. A: RNA in situ hybridization showing Nov expression in subcutaneous (arrow head), body wall (filled arrow) and intervertebral muscles (arrow) in El6.5 embryos. B, C: photographs of wild type (B) and Novdel3-/- (C) body walls, showing thinning and transparency in the mutant. D-I: Haematoxylin and Eosin stained sections of adult skin from wild type $(D, G)$, Novdel3 $+/-(E, H)$ and Novdel3-/- $(F, I)$ mice showing atrophy of subcutaneous muscles in Novdel3+/- and Novdel3-/- mice, with arrow heads marking the residual muscle layer. Histology of the subcutaneous adipose tissue in wild type $(\mathrm{J})$ and Novdel3-/- $(\mathrm{K})$ showing large mature fat cells in the wild type in contrast to the mixture of large (mature) and small (immature) fat cells in the mutant. L, M: Haematoxylin and Eosin stained section of adult intercostal muscles in wild type $(\mathrm{L})$ and Novdel3 $/-(\mathrm{M})$ mice showing muscle atrophy and transdifferentiation to fat in the mutant. Scale bars in $A=20 \mu \mathrm{m} ; \mathrm{D}-\mathrm{F}=50 \mu \mathrm{m} ; \mathrm{G}-\mathrm{M}=10 \mu \mathrm{m}$.

mutant with loss of the surface epithelium and fragmentation of the abnormal lens tissue (Figure 7C-F).

\section{Discussion}

We have generated by gene targeting Nov del3-/- mice that reveal diverse roles of NOV in the developing embryo and in tissue maintenance in adult mice. These mice produce no full length NOV protein, but express at a barely detectable level a mutant NOV protein that lacks the VWC domain. The low level of the mutant protein was in contrast to the expression level of its mRNA, which in PEFs was comparable to that of the wild type transcript, sug- gesting that deletion of the VWC domain might lead to reduced NOV protein stability.

Interestingly, we have detected by RT-PCR an equivalent Nov transcript also lacking the VWC domain in several tissues in the developing wild type mouse embryo at E16.5 (DT, CB unpublished observations). Sequence analysis of the RT-PCR product confirms that this is a naturally occurring splice variant lacking exon 3 and hence the VWC domain. We note that a splice variant of WISP1 similarly lacking the VWC domain has also been reported [35]. In CTGF, the VWC domain has been shown to enhance TGF $\beta$ 


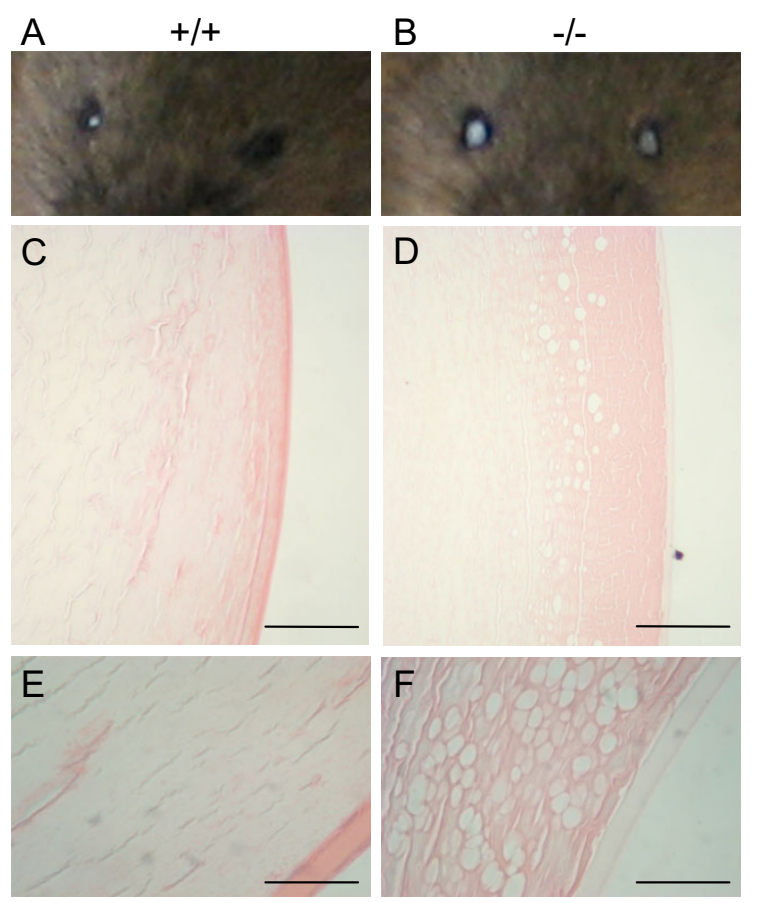

Figure 7

Phenotype of adult lens. A, B: Photograph of eyes of wild type (A) and Novdel3_/- (B) adult mice of six months of age, showing cataracts in both eyes in the mutant. The small white colouration in the wild type eye is an artefact due to reflected light. C-F: Haematoxylin and Eosin stained sections of wild type (C,E) and Novdel3-/- (D,F) adult eyes showing degeneration of the mutant lens, with vacuolation and loss of surface epithelium. Scale bars in E,F $=5 \mu \mathrm{m} ; C, D=15 \mu \mathrm{m}$.

binding to its receptor and inhibit BMP4 signalling [7]. It is therefore possible that variant NOV and WISP1 proteins lacking this domain may therefore be functionally distinct from full length NOV and WISP1.

On the basis of the analysis of Novdel3_/- mice, we cannot conclude whether the phenotypes observed are due to the loss of full length NOV function, or to possible novel functions of the very low level of NOVdel3 produced. The diverse range of phenotypes of $\mathrm{Nov}^{\text {del3 }}$ homozygotes was also seen, albeit to a less severe extent, in Nov del3 heterozygotes. This would be consistent either with haploinsufficiency of the single remaining intact Nov gene, or alternatively that a low level of NOVdel3 mutant protein has a dominant effect. Indeed, preliminary experiments suggest that forced expression of Novdel3 in 10T1/2 fibroblasts affects their differentiation, suggesting that it can indeed have biological activity, although differences in the expression level, in cell types and developmental context involved mean that we cannot conclude whether this protein contributes to the Novdels-/- in vivo phenotype.
Resolution of this point will require generation of mice that are homozygous for a true null mutation in the Nov gene, and to date we have been unsuccessful in achieving this, for reasons unknown. Hence, in the absence of the NOV null mutant, it is not possible to determine whether the phenotypes are due to loss or reduction in the level of full length NOV, the $\mathrm{NOV}^{\text {del3 }}$ mutant protein or a combination of both.

The phenotypes seen in the Novdels mutant mice show both significant similarities and differences with knockouts of other CCN genes, discussed in more detail in later sections. Phenotypes were observed in both Novdel3 heterozygotes and homozygotes, affected a variety of different tissues and resulted in embryonic or neonatal lethality of a subset of offspring. In these respects, the Nov mutant differs from the reported Cyr61 and Ctgf knockout mice, both of which are null mutants with lethality of all homozygotes in utero (Cyr61) or shortly after birth (Ctgf), although we cannot conclude whether the NOVdel3 protein is sufficient to rescue an otherwise embryonic lethality. While Nov is expressed in the smooth muscle and endothelial cells of the major vessels, no severe abnormalities were observed in these tissues, in contrast to the Cyr61 knockout homozygotes which die in midgestation with placental defects and loss of vascular integrity [25]. However, Novdel3-/- embryos did exhibit abnormalities in the endocardial cushions and delay in septal fusion which has also been found in Cyr 61-/- embryos [36]. As in the Ctgf knockout homozygotes, many Novdel3_ /- offspring had abnormalities in skeletal development, but with significant differences in phenotypes, as discussed below. Joint abnormalities were also observed in the Novdel3 mutants both before and after birth; this has not been reported for the Ctgf knockout. Mutations in another CCN family member, WISP3, cause progressive pseudorheumatoid dysplasia in man [26], although the mouse knockout in Wisp3 had no overt phenotype, suggesting that its loss in the mouse can be compensated for by another gene.

\section{Abnormal skeletogenesis and joint formation in Novdel3 mutant mice}

$N o v^{d e l 3}+/$ - and Novdel3_/- mice exhibited multiple defects in skeletogenesis and joint formation. Overgrowth of the appendicular and axial skeleton was observed, with enlargement of vertebrae, long bones and digits, and fusion of tarsal bones in the foot. The cartilage elements were expanded in the Novdels-/- embryos compared to wild type littermates, seen both in whole skeletal preparations at E16.5, E18.5 (data not shown) and E19.5 and in sectioned embryos at E16.5. Enhanced chondrogenesis was also seen in micromass cultures in vitro, with stronger staining with Alcian blue after 5 days in culture and increased diameters of the micromasses at 9 days. It will 
be of interest to determine whether this reflects increased proliferation and/or migration of chondrocytes and/or enhanced differentiation of mesenchymal cells down the chondrogenic pathway. Terminal chondrogenic differentiation in Novdel3_/- embryos was also affected; the morphology of the pre-hypertrophic cells and surrounding matrix was abnormal and ossification of hypertrophic cartilage was delayed, with a shortening of the pre-hypertrophic/hypertrophic zone and disruption of the sharp transition between proliferative columnar cells and quiescent pre-hypertrophic cells present in wild type embryos. Yu et al. [34], have reported that NOV is expressed in prehypertrophic and early hypertrophic chondrocytes, and that down-regulation of NOV expression by administration of parathyroid hormone-related protein (PTHrP), coincides with a delay in terminal differentiation. Lafont et al. [37], showed that administration of exogenous NOV up-regulated TGF $\beta 2$ and Collagen $\mathrm{X}$, a marker of hypertrophic chondrocytes, suggesting that NOV acts as a promoter of late chondrocyte differentiation. A detailed molecular analysis of chondrogenic differentiation in the Novdel3_/- embryos will shed further light on the role of NOV in this pathway.

Although there was a delay in ossification of hypertrophic chondrocytes, an overall increase in the thickness of the bone collar and in the intensity of staining of the bone matrix with Von Kossa was observed in the Novdel3-/embryos. The increased mineralization observed in the mutants may reflect enhanced differentiation down the osteogenic pathway, as the differentiation of mesenchymal cells to osteoblasts was promoted in PEFs and in micromasses derived from Nov del3_/- embryos. Our results are consistent with recent data from Rydziel and co-workers showing that over-expression of Nov inhibits osteoblastogenesis and causes osteopenia in transgenic mice expressing Nov from the osteocalcin promoter [38]. These authors show convincingly that the inhibition of osteogenic differentiation is achieved through NOV directly binding and inhibiting the activity of BMP2, a key regulator of skeletogenesis. They also showed that NOV has Wnt3/ $\beta$-catenin antagonistic activity, but this was not via a direct interaction with Wnt3 or its co-receptor LRP-6. The increased bone mineralization we observed in the Novdels-/- and Novdels $+/-$ mice is also consistent with the decrease in mineral apposition rate seen in the Nov transgenic mice described by Rydziel et al. which they ascribe to impaired osteoblastic function. Minamizato et al. [39] also reported that over-expression of Nov blocked osteogenic differentiation by interacting with and inhibiting BMP2, and also by activating Notch signalling; this conflicts with the results of Rydziel et al. who found that NOV inhibited Notch signalling in osteoblastic cells.
Our results differ significantly from those seen in CTGF knockout mice which die shortly after birth with severely malformed rib cages. As in the Novdel3 mutants, delayed ossification was also observed, but in this case the prehypertrophic/hypertrophic zone was enlarged and the Ctgf-/- mice exhibited thinner bone collars. In contrast, in the Novdel3 mutants, the size of the prehypertrophic/hypertrophic zone was reduced, and the bone collars were increased in thickness. In the Ctgf-/- mice, the delay in ossification reflects a requirement for CTGF in the coordination of ossification and angiogenesis. We have not studied angiogenesis in the Nov dels_/- mice, but it is known that NOV can act as an angiogenic factor [40], and this might therefore also contribute to the delay in ossification seen in the Nov mutants. The differences seen in the skeletal phenotypes of the Ctgf and Nov mutants may reflect the different roles played by these proteins in osteoblast differentiation. In a cell culture system in which mesenchymal stem cells were induced to differentiate down the osteogenic pathway on induction with Wnt3A, Ctgf, together with Cyr61 and Wisp2 were significantly upregulated, whereas Nov was not [41]. In this system, Cyr61 was a direct target of Wnt $/ \beta$ catenin signalling and RNA interference-mediated knockdown of Cyr61 reduced Wnt3A induced osteogenic differentiation. This contrasts markedly with the effects of NOV on inhibiting the osteogenic differentiation of ST-2 stromal cells and MC3T3 osteoblastic cells [38], which is mediated by direct inhibition of BMP2 and indirect inhibition of Wnt $/ \beta$ catenin signalling. The increased bone collar thickness in the Novdel3 -/embryos would be consistent with an increase in Wnt3 signalling, as activating mutations in the Wnt receptor LRP5 cause high bone density in man $[42,43]$ while loss of function mutations in this gene cause the reduced bone density seen in the autosomal recessive disorder osteoporosis-pseudoglioma syndrome [44]. It will be of interest to determine whether Wnt $3 / \beta$ catenin signalling is increased in the skeletal system of $\mathrm{Nov}^{d e l 3}$ mutants. Further investigation into the mechanisms underlying the modifications in bone formation and remodelling in $\mathrm{Nov}^{d e l 3}$ mutant mice is currently underway.

Unlike Ctgf, Nov is very highly expressed in the myotendenous junctions during skeletal development, and abnormalities in joint formation were seen in both $\mathrm{Nov}^{\text {del3 }}+/$ and Novdels-/- mice. In adult mutant mice, knee deformities were particularly prominent, characterised by expansion of the meniscus and abnormalities of the articular surfaces. Mutations in WISP3 (CCN6) are associated with joint abnormalities in man, causing progressive pseudorheumatoid dysplasia, characterised by juvenile-onset cartilage degeneration [26], although Wisp3 knockout mice have no overt phenotype [45]. Our results suggest a possible involvement for NOV in diseases of the joints and further support the idea that multiple members of the $\mathrm{CCN}$ 
family are required for normal formation and homeostasis of the skeleton.

\section{Nov affects heart development and causes cardiomyopathy in adult mice}

Our results show for the first time a requirement for NOV in heart development. Nov is expressed highly in the smooth muscle and endothelial cells of the major vessels, including the aorta and pulmonary trunk, and in a subset of cells near the base of the great vessels [32,33]. Although the major vessels appeared overtly normal in the Novdel3-/ - embryos, abnormalities in the growth and modelling of the endocardial cushions were seen and a delay in fusion of the ventricular septum was noted. Novdel3_/- and Novdel3 +/- adults developed cardiomyopathy characterised by hypertrophy of the septal wall and calcification. Similar defects are also seen in knockout mice lacking the gap junction protein Connexin 43 (Cx43) [46]. Homozygous Cx43 knockout mice die shortly after birth with malformation of the conotruncal heart segment leading to ventricular outflow obstruction; these mice also exhibit hypertrophy of the septum and calcification. Interestingly, NOV has been shown to interact directly with Cx43 [47] and Cx43 null homozygotes also exhibit delayed ossification and osteoblast dysfunction. Skeletal and cardiovascular defects are also a feature of knockout mice with disrupted BMP signalling [48]. BMP4 is expressed in the outflow tract (OFT) myocardium and in the endocardial cushions from E12-E14 in the mouse while BMP2 is expressed in the atrioventricular canal and valves [49]. By generating knockout mice with a mutated BMP type II receptor with reduced signalling capability, Delot et al. [50], have shown that BMP signalling is required for growth of the OFT cushions, OFT septation and formation of the semilunar valves. The demonstration that NOV binds directly to BMPs and inhibits their activity in osteogenesis [38] raises the possibility that abnormalities in endocardial cushion development and ventricular septation of $\mathrm{Nov}^{\text {del3 }}$ mutants may be mediated through alterations in BMP signalling.

A requirement for another CCN family member, CYR61, in development of the endocardial cushions has recently been reported [36]. Cyr61-/- embryos exhibit severe atrioventricular septal defects (AVSD) as a result of abnormal valvuloseptal morphogenesis. Interestingly, delayed formation of the ventricular septum is also seen in Cyr61 +/embryos, and approximately $20 \%$ of Cyr61 +/-adults have persistent ostium primum atrial septal defects (ASD). Thus, haploinsufficency for Cyr61 causes cardiac defects, indicating that its level of expression is critical for normal heart development. We also see cardiac defects in adult $\mathrm{Nov}^{\text {dels }}$ heterozygotes, as well as abnormalities in other tissues, which would be consistent with haploinsufficency for Nov, although it is also possible that these phenotypes could be due to a dominant effect of the NOVdel3 mutant protein.

\section{Muscle atrophy and transdifferentiation of myocytes to adipocytes in Novdel3 homozygotes and heterozygotes}

Nov is expressed highly in specific muscles during mouse development, notably the subcutaneous muscles, and a subset of hypaxial muscles: body wall, intercostal, intervertebral, hip and shoulder muscles [32]. All of these muscles developed in Novdel3-/- and Novdel3+/- embryos, but underwent premature degeneration by five months of age in the adult. Muscle atrophy was associated with transdifferentiation to fat, with the characteristic morphology of immature adipocytes. Thus, NOV is required for muscle maintenance and viability. It will be of interest to determine whether the satellite cells, which are the stem cell population involved in muscle regeneration, are normal in these mice, as we saw little evidence of muscle regeneration taking place in the atrophied areas.

There is increasing evidence that NOV is a key regulator of myogenesis. In vitro, Nov over-expression in C2C12 cells results in inhibition of terminal muscle differentiation; there is some controversy about whether this is achieved via direct activation of Notch signalling, as reported by Sakamoto et al. [51], or not [52]. We have found that over-expression of Nov pushes 10T1/2 mesenchymal cells down the myogenic pathway, promoting the proliferation and survival of cells expressing myogenin, but blocking terminal differentiation, thus resulting in expansion of the myogenic population (EH, DT, EA, CB personal observations). The muscle cells present in Wilms' tumours exhibiting heterotypic differentiation express a high level of Nov [29], consistent with the hypothesis that inappropriate expression of Nov may contribute to the abnormal differentiation of mesodermal cells to muscle in some Wilms' tumours. Elevated Nov expression is found in musculoskeletal tumours, including alveolar rhabdomyosarcomas [31]. These tumours are thought to originate from a multipotential mesenchymal cell type and are correlated with translocations between chromosomes 1 or 2 and chromosome 13, resulting in the generation of Pax3- or Pax7-forkhead (Pax3-7/FKHR) chimaeric genes [53,54].

There is evidence to suggest that the balance between myogenic and adipogenic potential in myoblasts is regulated by Wnt signalling, with Wnt10b deficiency associated with increased potential for adipogenic differentiation in myoblasts [55]. These authors have proposed that down regulation of Wnt10b signalling may contribute to the impaired muscle regenerative capacity and increased muscle adiposity characteristic of aged muscle. Given that different $\mathrm{CCN}$ family members either are induced by Wnts or can themselves modulate Wnt signal- 
ling, it would be of interest to determine whether Wnt $10 \mathrm{~b}$ signalling is affected in Novdel3-/- and $\mathrm{Nov}^{d e l}{ }_{3}$ /- mice.

\section{Premature cataract formation in Novdel3 homozygotes and heterozygotes}

Premature lens degeneration was seen in both Novdel3_/and $\mathrm{Nov}^{\mathrm{del} 3}+/$ - mice, with early onset cataract formation from six months of age. This was characterised by vacuolation of the lens and loss of the surface epithelium. Cataract formation is very rarely seen in wild type $129 / \mathrm{Sv}$ mice of less than twelve months of age, and we found no evidence of this in wild type littermates. Its early onset is also a feature of mice lacking the gap junction protein Connexin 46 (Cx46) [56]. In view of the direct interaction of NOV with $\mathrm{Cx} 43$ [47], it would be of interest to determine whether NOV interacts with $\mathrm{Cx} 46$ and is required for normal gap junction communication in the lens.

\section{Nov and maintenance of tissue viability}

The cardiomyopathy, muscle atrophy, cataracts and joint abnormalities seen in the Novdel3-/- and Novdel3+/- mice suggest that NOV may have a general role to play in maintenance of tissue viability in adults. This would be consistent with other features of early aging that we have noted in our mice, including hair loss and abnormally low levels of body fat in older animals (EH, CB unpublished observations). NOV has also been implicated in wound healing [40], and has recently been shown to be a key regulator of human haematopoetic stem/progenitor cells [57]. The Novdel3 heterozygous and homozygous mice described here will provide a valuable resource to test the potential involvement of NOV in a variety of processes including stem cell behaviour, tissue regeneration and wound healing.

\section{Conclusion}

There is increasing evidence that CCN family members are important modulators of matricellular signalling in development and disease. In this paper we report the generation of the first mouse mutant in the Nov gene; these mice reveal diverse functions for NOV in the embryo and adult and demonstrate for the first time the importance of this protein in organogenesis and in tissue homeostasis and viability in adult mice. We showed that mutation of Nov causes overgrowth of the axial and appendicular skeleton, delayed ossification, and severe joint abnormalities. Fibroblasts derived from Novdels homozygotes are potentiated to differentiate down the osteogenic pathway, showing the importance of NOV in regulating cell fate decisions and differentiation. We showed that normal NOV function is essential for heart development and that its mutation causes cardiomyopathy in adult mice. This is also the first demonstration that NOV is essential for tissue homeostasis, with premature degeneration of specific muscles and lenses in Novdels homozygotes and heterozy- gotes; these mice may thus provide valuable insights into the processes of tissue viability and aging. A key question in development is how multiple signalling pathways are co-ordinated to orchestrate the complex processes of organogenesis in the embryo and tissue homeostasis in the adult. The Novdel3 mutants described here represent a valuable resource for dissecting these processes at the molecular and cellular level, as well as providing a mouse model for studying diseases affecting the heart, skeleton, muscles and lens.

\section{Methods}

Generation of constructs, targeted ES cell lines and mice

The targeting construct contained $3.0 \mathrm{~kb}$ of $5^{\prime}$ homology from the XbaI site $1.5 \mathrm{~kb}$ upstream of the Nov start codon to the first PstI site in intron 2. The 3 ' homology is $3.1 \mathrm{~kb}$ from the HindIII site in intron 3 to the BamHI site at the 3 'end of intron 4. A TkneopolyA cassette was inserted between the two Nov arms and a HSVTK negative selection cassette was inserted downstream of the 3' homology. CCB 129Sv ES cells were electroporated and selected with $0.3 \mathrm{mg} / \mathrm{ml} \mathrm{G} 418$ and $1 \mathrm{mM}$ Gancyclovir. Colonies were screened by PCR and positive targets confirmed by Southern analysis using external probes (Figure 1A). Germline chimaeras were obtained by injecting karyotypically normal targeted cells into $\mathrm{C} 57 \mathrm{Bl} / 6$ blastocysts and the targeted line was maintained on a 129Sv background.

\section{Derivation and culture of primary cells}

Primary embryo fibroblasts (PEFs) were isolated from E13.5 embryos obtained from heterozygous matings and genotyped by PCR using yolk sac DNA. For routine cellular maintenance, PEFs were maintained in Dulbecco's modified Eagle's medium (Invitrogen) containing 10\% fetal calf serum. To study chondrogenic/osteogenic differentiation, cells were either plated in high density micromass cultures using the technique of Ahrens et al. [58], or as monolayer cultures in 6-well plates seeded at a density of $10^{5}$ cells/well. Cultures were maintained in Ham's F12 medium (Invitrogen) containing 10\% fetal calf serum. PEF cultures were fixed with $4 \%(\mathrm{w} / \mathrm{v})$ paraformaldehyde and stained overnight with 1\% Alcian Blue 8-GX (pH 1.0) to detect cartilage matrix sulfated glucosaminoglycans [59] or assayed for alkaline phosphatase enzymatic activity by incubation with Sigma Fast BCIP/NBT alkaline phosphatase substrate at $37^{\circ} \mathrm{C}$ for 10 minutes.

\section{Reverse transcription RT-PCR and In situ hybridisation}

Total RNA was extracted from cultured PEFs using the RNeasy kit (Qiagen) according to manufacturer's instructions. RNA was treated with RNAse free DNAse I and reverse-transcribed using Superscript II (Invitrogen). cDNAs were amplified by PCR using the following primers: 
Gapdh s GCATGGACTGTGGTCATGAG and as CCATCACCATCTTCCAGGAG; Nov specific primers: Nov exon1 s GATGCCTCTGCCTAGGCTTC and Nov exon4 as CACACTGGCGATTCCTGTTG, Alkaline phosphatase s CCTGCAGGATCGGAACG and as GACCTGAGCGTTGGTGTTATATGT; Collagen $\quad I \quad s$ AGCACCACGGCAGCAGGAGGTTT and as CAGGGTTGCCAGGAGGTCCAACA; Osteocalcin s CCAAGCAGGAGGGCAATA and as AGGGCAGCACAGGTCCTAA. RNA in situ hybridization was performed on E16.5 embryo cryostat sections as previously described [32].

\section{Protein isolation and immunoblot analysis}

For whole cell protein lysates, cells were lysed with RIPA buffer and protein concentrations determined using the Bradford assay (Sigma). For Western analysis, $10 \mu \mathrm{g}$ of each protein sample was subjected to SDS-PAGE (12\%) and electrotransferred onto Hybond-P nitrocellulose membranes (GE Healthcare). Blots were probed with a rabbit polyclonal anti-NOV antibody 59.3 (1:1000) raised against a c-terminal NOV peptide (CPQNNEAFLQDLELKTS) which recognizes both full-length NOV (40 kDa) and mutant NOVdel3 proteins $(30 \mathrm{kDa})$ or anti- $\alpha$-tubulin antibody (clone B-5-1-2, 1:3000, Sigma). Proteins were visualized with anti-mouse or anti-rabbit IgG horseradish-peroxidase-linked antibodies (1:25,000; Santa Cruz Biotechnologies) using the ECL detection system (GE Bioscience). To confirm equal protein loading of conditioned media samples, parallel gels were run and stained with Coomassie Brilliant Blue.

\section{Skeletal preparation and histology}

Alcian blue and Alizarin red staining of cleared skeletal preparations was performed according to Hogan et al. [60]. For histology, specimens were fixed in $4 \%(\mathrm{w} / \mathrm{v})$ paraformaldehyde and embedded in paraffin. Deparaffinized sections $(5 \mu \mathrm{m})$ were stained with Haematoxylin and Eosin, Alcian blue and Nuclear Fast Red or Von Kossa. Immunostaining for PCNA was carried out on deparaffinized sections after antigen retrevial with $0.1 \mathrm{M}$ sodium citrate using a monoclonal anti-PCNA antibody (1:500, sc56, Santa Cruz Biotechnologies) and staining detected with the Vectastain Elite Mouse IgG ABC Kit (Vector Laboratories) according to the manufacturers' instructions.

\section{Authors' contributions}

EH contributed to the preparation of the manuscript and performed most of the phenotypic characterisation of the Novdel3 mutants. DT carried out a significant amount of initial work on the Novdel3 mutants. EA constructed the targeting construct and isolated the targeted ES cell clones. PS was a co-applicant on the Wellcome grant funding EA and was involved in some of the discussions about the work. SF contributed valuable pathology expertise in analysing the phenotype of the Novdel3 mutants. CAB was the principal applicant on the Wellcome Trust and BBSRC project grants that funded the work, conceived and directed the project, generated the $\mathrm{Nov}^{d e l 3}$ mice and wrote the paper.

\section{Additional material}

\section{Additional file 1}

Expression analysis of Nov in wild type and Nov del3 primary embryonic fibroblasts (PEFs). Semi-quantitative RT-PCR of full-length Nov (FL Nov) and mutant Nov del3 transcripts (Novdel3) in PEFs using Nov exon 1 and exon 4 primers. Wild type (+/+) PEFs express full-length Nov, whereas Novdel3 -/- PEFs express only Nov del3 transcripts lacking exon 3. Two fold serial dilutions of cDNA were used and normalised to gapdh. Click here for file

[http://www.biomedcentral.com/content/supplementary/1471213X-8-18-S1.ppt]

\section{Additional file 2}

Serial sections of E13.5 wild type and Novdel3 hearts. Haematoxylin and Eosin staining of transverse serial sections of E13.5 wild type (A-D) and Novdel3 -/- (E-H) embryonic hearts showing abnormal growth and modelling of endocardial cushions (EC) and delay in fusion of the septum (S) in the mutant embryos (Arrow in E-H). Scale bars, $10 \mu \mathrm{m}$.

Click here for file

[http://www.biomedcentral.com/content/supplementary/1471213X-8-18-S2.ppt]

\section{Acknowledgements}

We would like to thank Dr. P. Ellis for assistance with the initial screening for targeted ES cells and Dr Dipa Natarajan for Nov RNA in situ hybridization. This work was funded by the BBSRC, the Wellcome Trust and Kidney Research UK (KRUK). DT was in receipt of a studentship from Peterhouse College, Cambridge. SF is supported by Tenovus Tayside. CAB is a KRUK Senior Research Fellow.

\section{References}

I. Leask A, Abraham DJ: All in the CCN family: essential matricellular signaling modulators emerge from the bunker. J Cell Sci 2006, I I 9(Pt 23):4803-48I0.

2. Bork P: The modular architecture of a new family of growth regulators related to connective tissue growth factor. FEBS Lett 1993, 327(2): I25- I30.

3. Brigstock DR: The connective tissue growth factor/cysteinerich $6 \mathrm{I} /$ nephroblastoma overexpressed (CCN) family. Endocr $\operatorname{Rev} 1$ 999, 20(2): 189-206.

4. Mason ED, Konrad KD, Webb CD, Marsh JL: Dorsal midline fate in Drosophila embryos requires twisted gastrulation, a gene encoding a secreted protein related to human connective tissue growth factor. Genes $\operatorname{Dev} 1$ 1994, 8(13): | 489-I50I.

5. Oelgeschlager M, Larrain J, Geissert D, De Robertis EM: The evolutionarily conserved BMP-binding protein Twisted gastrulation promotes BMP signalling. Nature 2000, 405(6788):757-763.

6. Chang C, Holtzman DA, Chau S, Chickering T, Woolf EA, Holmgren LM, Bodorova J, Gearing DP, Holmes WE, Brivanlou AH: Twisted gastrulation can function as a BMP antagonist. Nature 200I, 41 0(6827):483-487.

7. Abreu JG, Ketpura NI, Reversade B, De Robertis EM: Connectivetissue growth factor (CTGF) modulates cell signalling by BMP and TGF-beta. Nat Cell Biol 2002, 4(8):599-604.

8. Segarini PR, Nesbitt JE, Li D, Hays LG, Yates JR 3rd, Carmichael DF: The low density lipoprotein receptor-related protein/ 
alpha2-macroglobulin receptor is a receptor for connective tissue growth factor. J Biol Chem 200I, 276(44):40659-40667.

9. Gao R, Brigstock DR: Low density lipoprotein receptor-related protein (LRP) is a heparin-dependent adhesion receptor for connective tissue growth factor (CTGF) in rat activated hepatic stellate cells. Hepatol Res 2003, 27(3):2। 4-220.

10. Brose K, Tessier-Lavigne M: Slit proteins: key regulators of axon guidance, axonal branching, and cell migration. Curr Opin Neurobiol 2000, I 0(I):95-102.

II. Nishida T, Kubota S, Fukunaga T, Kondo S, Yosimichi G, Nakanishi T, Takano-Yamamoto T, Takigawa M: CTGF/Hcs24, hypertrophic chondrocyte-specific gene product, interacts with perlecan in regulating the proliferation and differentiation of chondrocytes. J Cell Physiol 2003, I 96(2):265-275.

12. Grzeszkiewicz TM, Lindner V, Chen N, Lam SC, Lau LF: The angiogenic factor cysteine-rich 6 I (CYR6I, CCNI) supports vascular smooth muscle cell adhesion and stimulates chemotaxis through integrin alpha(6)beta(I) and cell surface heparan sulfate proteoglycans. Endocrinology 2002, | 43(4): | 44|- | 450.

13. Vitt UA, Hsu SY, Hsueh AJ: Evolution and classification of cystine knot-containing hormones and related extracellular signaling molecules. Mol Endocrinol 200 I, I 5(5):68I-694.

14. Mercurio S, Latinkic B, Itasaki N, Krumlauf R, Smith JC: Connectivetissue growth factor modulates WNT signalling and interacts with the WNT receptor complex. Development 2004, |3 |(9):2|37-2| 47.

15. Itasaki N, Jones CM, Mercurio S, Rowe A, Domingos PM, Smith JC Krumlauf R: Wise, a context-dependent activator and inhibitor of Wnt signalling. Development 2003, I 30(18):4295-4305.

16. Latinkic BV, Mercurio S, Bennett B, Hirst EM, Xu O, Lau LF, Mohun TJ, Smith JC: Xenopus Cyr6I regulates gastrulation movements and modulates Wnt signalling. Development 2003 I 30(II):2429-244I.

17. Lau LF, Lam SC: The CCN family of angiogenic regulators: the integrin connection. Exp Cell Res 1999, 248(I):44-57.

18. Kireeva ML, Mo FE, Yang GP, Lau LF: Cyr6I, a product of a growth factor-inducible immediate-early gene, promotes cell proliferation, migration, and adhesion. Mol Cell Biol 1996, 16(4):1326-1334.

19. Babic AM, Chen CC, Lau LF: Fisp/2/mouse connective tissue growth factor mediates endothelial cell adhesion and migration through integrin alphavbeta3, promotes endothelial cell survival, and induces angiogenesis in vivo. Mol Cell Biol 1999, 19(4):2958-2966.

20. Chen CC, Mo FE, Lau LF: The angiogenic factor Cyr6I activates a genetic program for wound healing in human skin fibroblasts. Biol Chem 200I, 276(50):47329-47337.

21. Grzeszkiewicz TM, Kirschling DJ, Chen N, Lau LF: CYR6I stimulates human skin fibroblast migration through Integrin alpha vbeta 5 and enhances mitogenesis through integrin alpha vbeta 3 , independent of its carboxyl-terminal domain. J Biol Chem 200I, 276(24):21943-21950.

22. Wong M, Kireeva ML, Kolesnikova TV, Lau LF: Cyr6I, product of a growth factor-inducible immediate-early gene, regulates chondrogenesis in mouse limb bud mesenchymal cells. Dev Biol 1997, 1 92(2):492-508.

23. Su F, Overholtzer M, Besser D, Levine AJ: WISP-I attenuates p53. mediated apoptosis in response to DNA damage through activation of the Akt kinase. Genes Dev 2002, I6(I):46-57.

24. Ivkovic S, Yoon BS, Popoff SN, Safadi FF, Libuda DE, Stephenson RC Daluiski A, Lyons KM: Connective tissue growth factor coordinates chondrogenesis and angiogenesis during skeletal development. Development 2003, I30(I 2):2779-279I.

25. Mo FE, Muntean AG, Chen CC, Stolz DB, Watkins SC, Lau LF CYR6I (CCNI) is essential for placental development and vascular integrity. Mol Cell Biol 2002, 22(24):8709-8720.

26. Hurvitz JR, Suwairi WM, Van Hul W, El-Shanti H, Superti-Furga A, Roudier J, Holderbaum D, Pauli RM, Herd JK, Van Hul EV, Rezai-Delui $\mathrm{H}$, Legius E, Le Merrer M, Al-Alami J, Bahabri SA, Warman ML: Mutations in the CCN gene family member WISP3 cause progressive pseudorheumatoid dysplasia. Nat Genet 1999 23(1):94-98

27. Joliot V, Martinerie C, Dambrine G, Plassiart G, Brisac M, Crochet J, Perbal B: Proviral rearrangements and overexpression of a new cellular gene (nov) in myeloblastosis-associated virus type I-induced nephroblastomas. Mol Cell Biol 1992, I 2(I): |0-2|.

28. Martinerie C, Huff V, Joubert I, Badzioch M, Saunders G, Strong L, Perbal B: Structural analysis of the human nov proto-oncogene and expression in Wilms tumor. Oncogene 1994, 9(9):2729-2732.

29. Chevalier G, Yeger H, Martinerie C, Laurent M, Alami J, Schofield PN, Perbal $B$ : novH: differential expression in developing kidney and Wilm's tumors. Am J Pathol 1998, I52(6):।563-I575.

30. Pajer P, Pecenka V, Kralova J, Karafiat V, Prukova D, Zemanova Z, Kodet R, Dvorak M: Identification of potential human oncogenes by mapping the common viral integration sites in avian nephroblastoma. Cancer Res 2006, 66(I):78-86.

31. Manara MC, Perbal B, Benini S, Strammiello R, Cerisano V, Perdichizzi S, Serra M, Astolfi A, Bertoni F, Alami J, Yeger H, Picci P, Scotlandi K: The expression of ccn3(nov) gene in musculoskeletal tumors. Am J Pathol 2002, I60(3):849-859.

32. Natarajan D, Andermarcher E, Schofield PN, Boulter CA: Mouse Nov gene is expressed in hypaxial musculature and cranial structures derived from neural crest cells and placodes. Dev Dyn 2000, 21 9(3):4I7-425.

33. Kocialkowski S, Yeger H, Kingdom J, Perbal B, Schofield PN: Expression of the human NOV gene in first trimester fetal tissues. Anat Embryol (Berl) 200I, 203(6):4I7-427.

34. Yu C, Le AT, Yeger H, Perbal B, Alman BA: NOV (CCN3) regulation in the growth plate and $\mathrm{CCN}$ family member expression in cartilage neoplasia. J Pathol 2003, 201 (4):609-6I5.

35. Tanaka S, Sugimachi K, Saeki H, Kinoshita J, Ohga T, Shimada M, Maehara Y, Sugimachi K: A novel variant of WISPI lacking a Von Willebrand type $\mathbf{C}$ module overexpressed in scirrhous gastric carcinoma. Oncogene 200I, 20(39):5525-5532.

36. Mo FE, Lau LF: The matricellular protein CCNI is essential for cardiac development. Circ Res 2006, 99(9):96I-969.

37. Lafont J, Jacques C, Le Dreau G, Calhabeu F, Thibout H, Dubois C Berenbaum F, Laurent M, Martinerie C: New target genes for NOV/CCN3 in chondrocytes: TGF-beta2 and type $X$ collagen. J Bone Miner Res 2005, 20(I 2):22/3-2223.

38. Rydziel S, Stadmeyer L, Zanotti S, Durant D, Smerdel-Ramoya A, Canalis E: Nephroblastoma overexpressed (nov) inhibits osteoblastogenesis and causes osteopenia. I Biol Chem 2007, 282(27): 19762-19772.

39. Minamizato T, Sakamoto K, Liu T, Kokubo H, Katsube K, Perbal B Nakamura S, Yamaguchi A: CCN3/NOV inhibits BMP-2-induced osteoblast differentiation by interacting with BMP and Notch signaling pathways. Biochem Biophys Res Commun 2007 354(2):567-573.

40. Lin CG, Leu SJ, Chen N, Tebeau CM, Lin SX, Yeung CY, Lau LF: CCN3 (NOV) is a novel angiogenic regulator of the CCN protein family. J Biol Chem 2003, 278(26):24200-24208.

4I. Si W, Kang Q, Luu HH, Park JK, Luo Q, Song WX, Jiang W, Luo X, Li $X$, Yin $\mathrm{H}$, Montag AG, Haydon RC, He TC: CCNI/Cyr6I is regulated by the canonical Wnt signal and plays an important role in Wnt3A-induced osteoblast differentiation of mesenchymal stem cells. Mol Cell Biol 2006, 26(8):2955-2964.

42. Boyden LM, Mao J, Belsky J, Mitzner L, Farhi A, Mitnick MA, Wu D, Insogna K, Lifton RP: High bone density due to a mutation in LDL-receptor-related protein 5. N Engl J Med 2002, 346(20): I5I3-I52I.

43. Little RD, Carulli JP, Del Mastro RG, Dupuis J Osborne M, Folz C, Manning SP, Swain PM, Zhao SC, Eustace B, Lappe MM, Spitzer L, Zweier S, Braunschweiger K, Benchekroun Y, Hu X, Adair R, Chee L, FitzGerald MG, Tulig C, Caruso A, Tzellas N, Bawa A, Franklin B, McGuire S, Nogues X, Gong G, Allen KM, Anisowicz A, Morales AJ, Lomedico PT, Recker SM, Van Eerdewegh P, Recker RR, Johnson ML: A mutation in the LDL receptor-related protein 5 gene results in the autosomal dominant high-bone-mass trait. Am J Hum Genet 2002, 70(I): II-19.

44. Gong Y, Slee RB, Fukai N, Rawadi G, Roman-Roman S, Reginato AM, Wang H, Cundy T, Glorieux FH, Lev D, Zacharin M, Oexle K, Marcelino I, Suwairi W, Heeger S, Sabatakos G, Apte S, Adkins WN, Allgrove J, Arslan-Kirchner M, Batch JA, Beighton P, Black GC, Boles RG, Boon LM, Borrone C, Brunner HG, Carle GF, Dallapiccola B, De Paepe A, Floege B, Halfhide ML, Hall B, Hennekam RC, Hirose T, Jans A, Juppner H, Kim CA, Keppler-Noreuil K, Kohlschuetter A, LaCombe D, Lambert M, Lemyre E, Letteboer T, Peltonen L, Ramesar RS, Romanengo M, Somer H, Steichen-Gersdorf E, Steinmann B, Sul- 
livan B, Superti-Furga A, Swoboda W, van den Boogaard MJ, Van Hul W, Vikkula M, Votruba M, Zabel B, Garcia T, Baron R, Olsen BR, Warman ML: LDL receptor-related protein 5 (LRP5) affects bone accrual and eye development. Cell 200I, I07(4):5I3-523.

45. Kutz WE, Gong Y, Warman ML: WISP3, the gene responsible for the human skeletal disease progressive pseudorheumatoid dysplasia, is not essential for skeletal function in mice. Mol Cell Biol 2005, 25(I):4|4-42I.

46. Reaume AG, de Sousa PA, Kulkarni S, Langille BL, Zhu D, Davies TC, Juneja SC, Kidder GM, Rossant J: Cardiac malformation in neonatal mice lacking connexin43. Science 1995, 267(5205): $|83|-\mid 834$.

47. Gellhaus A, Dong X, Propson S, Maass K, Klein-Hitpass L, Kibschull M, Traub O, Willecke K, Perbal B, Lye SJ, Winterhager E: Connexin43 interacts with NOV: a possible mechanism for negative regulation of cell growth in choriocarcinoma cells. J Biol Chem 2004, 279(35):3693|-36942.

48. Yoon BS, Lyons KM: Multiple functions of BMPs in chondrogenesis. J Cell Biochem 2004, 93(1):93-103.

49. Abdelwahid E, Rice D, Pelliniemi LJ, Jokinen E: Overlapping and differential localization of Bmp-2, Bmp-4, Msx-2 and apoptosis in the endocardial cushion and adjacent tissues of the developing mouse heart. Cell Tissue Res 200I, 305(I):67-78.

50. Delot EC, Bahamonde ME, Zhao M, Lyons KM: BMP signaling is required for septation of the outflow tract of the mammalian heart. Development 2003, I30(I):209-220.

5I. Sakamoto K, Yamaguchi S, Ando R, Miyawaki A, Kabasawa Y, Takagi $\mathrm{M}, \mathrm{Li} \mathrm{CL}$, Perbal B, Katsube K: The nephroblastoma overex pressed gene (NOV/ccn3) protein associates with Notch I extracellular domain and inhibits myoblast differentiation via Notch signaling pathway. J Biol Chem 2002, 277(33):29399-29405.

52. Calhabeu F, Lafont J, Le Dreau G, Laurent M, Kazazian C, Schaeffer L, Martinerie C, Dubois C: NOVICCN3 impairs muscle cell commitment and differentiation. Exp Cell Res 2006, 3 I 2(10): 1876-1889.

53. Galili N, Davis RJ, Fredericks WJ, Mukhopadhyay S, Rauscher FJ 3rd, Emanuel BS, Rovera G, Barr FG: Fusion of a fork head domain gene to PAX3 in the solid tumour alveolar rhabdomyosarcoma. Nat Genet 1993, 5(3):230-235.

54. Davis RJ, D'Cruz CM, Lovell MA, Biegel JA, Barr FG: Fusion of PAX7 to FKHR by the variant $\mathrm{t}(1 ; \mid 3)(\mathrm{p} 36 ; \mathrm{q} \mid 4)$ translocation in alveolar rhabdomyosarcoma. Cancer Res 1994, 54(II):2869-2872.

55. Vertino AM, Taylor-Jones JM, Longo KA, Bearden ED, Lane TF, McGehee RE Jr., MacDougald OA, Peterson CA: Wntlob deficiency promotes coexpression of myogenic and adipogenic programs in myoblasts. Mol Biol Cell 2005, 16(4):2039-2048.

56. Gong X, Li E, Klier G, Huang Q, Wu Y, Lei H, Kumar NM, Horwitz J, Gilula NB: Disruption of alpha3 connexin gene leads to proteolysis and cataractogenesis in mice. Cell 1997, 9 I(6):833-843.

57. Gupta R, Hong D, Iborra F, Sarno S, Enver T: NOV (CCN3) functions as a regulator of human hematopoietic stem or progenitor cells. Science 2007, 3 | 6(5824):590-593.

58. Ahrens PB, Solursh M, Reiter RS: Stage-related capacity for limb chondrogenesis in cell culture. Dev Biol 1977, 60(I):69-82.

59. Lev R, Spicer SS: Specific Staining of Sulphate Groups with Alcian Blue at Low Ph. J Histochem Cytochem 1964, I 2:309.

60. Hogan BLM Beddington, R., Costantini, F. and Lacy, E.: Manipulating the Mouse Embryo: A Laboratory Manual. Cold Spring Harbor, NY: Cold Spring Harbor Laboratory Press 1994.
Publish with Biomed Central and every scientist can read your work free of charge

"BioMed Central will be the most significant development for disseminating the results of biomedical research in our lifetime. "

Sir Paul Nurse, Cancer Research UK

Your research papers will be:

- available free of charge to the entire biomedical community

- peer reviewed and published immediately upon acceptance

- cited in PubMed and archived on PubMed Central

- yours - you keep the copyright
BioMedcentral 